\title{
Indicators of Social Dialogue: Concepts and Measurements
}

Working Paper No. 5

Lane Kenworthy and Bernhard Kittel

Policy Integration Department Statistical Development and Analysis Group

International Labour Office

Geneva

May 2003

Working papers are preliminary documents circulated

to stimulate discussion and obtain comments 


\section{Indicators of Social Dialogue: Concepts and Measurement}

\section{Contents}

Preface

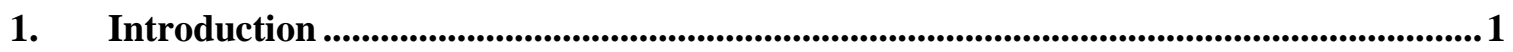

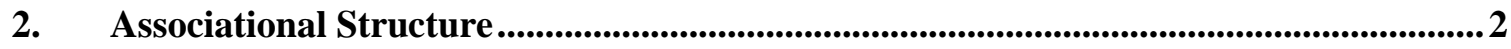

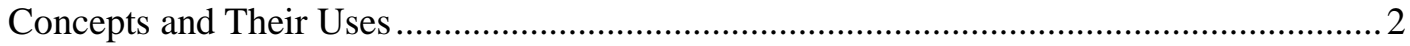

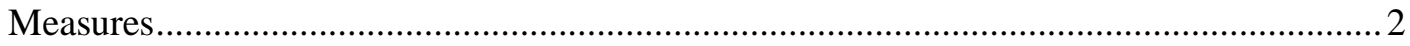

Recommendations for Data Collection........................................................................ 4

3. Wage-Setting Arrangements ..............................................................................................4

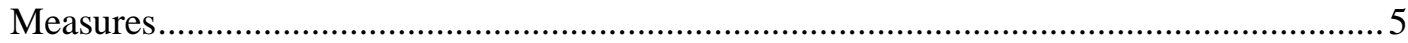

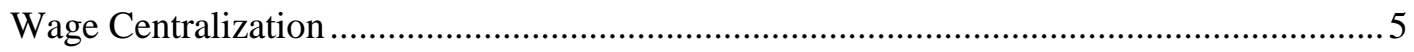

4. Participation in Public Policy ............................................................................. 12

Concepts and Their Uses ................................................................................... 12

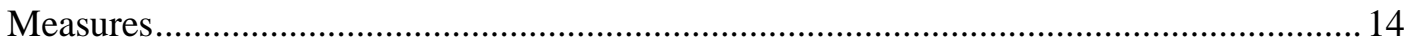

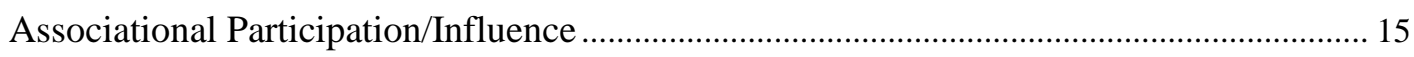

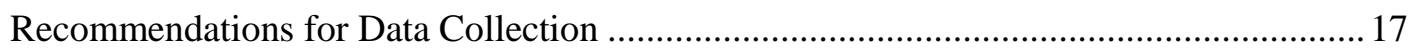

5. Firm-Level Representation ............................................................................... 18

6. Methods of Data Collection .................................................................................19

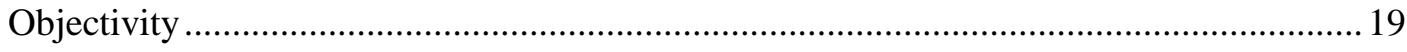

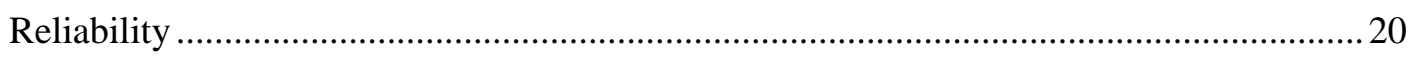

Validity 21

Recommendations for Data Collection ............................................................... 23

7. Summary and Conclusion............................................................................................23

Appendix: Existing Social Dialogue Indicators...................................................................... 24

Wage-Setting Arrangements......................................................................................................27

References........................................................................................................................... 31 


\section{Preface}

Social dialogue is one of the main pillars of Decent Work. It is seen by the ILO and others as not only helping to establish decent working conditions, but also as contributing to socio-economic progress and poverty reduction.

Social dialogue is typically defined as the process by which representatives of employers, workers and government exchange information and views, consult, negotiate and reach agreements on issues of concern to them. It is broad enough to encompass participation in public policy determination down to single-issue negotiations at the enterprise level. The manifestations that social dialogue takes reflect the diversity of labour relations systems around the globe. It is not obvious, however, how to measure the extent to which social dialogue occurs in a particular country. Nor is it obvious how one can gauge whether workers and employers actually exercise their rights to associate and bargain.

The ILO has recently started to explore how to measure decent work and progress toward decent work. Policy Integration Working Paper No. 2 (Measuring decent work with statistical indicators) provided a conceptual framework for such measurement, as well as suggesting a series of 30 indicators. Two of these indicators deal with social dialogue (union density rate and collective bargaining coverage rate). The paucity and relative superficiality of these social dialogue indicators was mainly due to the non-availability of relevant quality data for many countries.

In light of the lacunae of social dialogue indicators cross-nationally, discussions were held with officials in the ILO Infocus Programme on Promoting Social Dialogue (Patricia O'Donovan and Lucio Baccaro) on how it might be possible to measure social dialogue. This led to the co-commissioning of the present Working Paper by that programme and the Policy Integration Department's Statistical Development and Analysis Unit.

This Working Paper by Lane Kenworthy ${ }^{1}$ of the Department of Sociology at Emory University in Atlanta, United States, and Bernhard Kittel ${ }^{2}$ of the Max Planck Institute for the Studies of Societies in Cologne, Germany, makes a valuable contribution. They begin by classifying aspects of social dialogue into four categories: associational structure, wage setting arrangements, participation in public policy, and firm-level employee representation. By moving beyond what could be called the traditional social dialogue indicators of trade unions, and collective bargaining coverage, the authors help identify other institutional elements that are also very important for measuring and understanding social dialogue in its broad sense. The authors also discuss and draw out the implications of different methodological issues for data collection, categorisation and interpretation.

\footnotetext{
${ }^{1}$ Department of Sociology, Emory University, Atlanta, GA 30322, United States, Tel.: 1-404-727-7538;

Fax: 1-404-727-7532; e-mail lkenwor@emory.edu; homepage: http://www.emory.edu/SOC/LKENWORTHY

${ }^{2}$ Max Planck Institute for the Study of Societies, Paulstrasse 3, D-50676 Köln; Germany, Tel.: 49-221-2767-0;

Fax: 49-221-2767-555; e-mail: kittel @ mi-fg-koeln.mpg.de
} 
This working paper should help frame future work on the measurement of social dialogue indicators and hopefully generate further discussions, refinements and data collection of decent work indicators on social dialogue.

\section{Richard Anker}

Manager

Statistical Development and Analysis Unit

Policy Integration Department

March 2003 


\section{Indicators of Social Dialogue: Concepts and Measurement}

\section{Introduction}

In the past two decades a wealth of comparative research has examined the causes and consequences of institutions related to social dialogue in affluent OECD nations. One of the central findings of this research is that such institutions have contributed to cross-country differences and over-time developments in a variety of important socioeconomic outcomes, such as unemployment and the distribution of income. The institutions in question are ones in which workers and employers organize, negotiate with one another, and participate in policy-making processes. They fall into four broad categories: (1) associational structure; (2) wage-setting arrangements; (3) participation in public policy; (4) firm-level employee representation.

A generation ago, researchers interested in social dialogue focused largely on a single indicator: the extent of unionization. Although important, however, unionization represents only a small slice of the social dialogue picture. While there is little consensus regarding the socioeconomic impact of the various social dialogue institutions, a large number of studies have found effects of not only union density but also wage-setting arrangements and/or participation in policy making (see, e.g., Flanagan 1990; Traxler, Blaschke, and Kittel 2001). Moreover, some analyses have found that effects of unionization on outcomes such as unemployment work in the opposite direction to those of other aspects of social dialogue, such as the structure of wage setting (Kenworthy 2002; Nickell and Layard 1999).

Our concern in this report is with the conceptualization and measurement of social dialogue institutions. In sections 2 through 5 we provide an inventory of existing measures in each of the four categories, explore their principal features along with the similarities and differences among them, and offer our suggestions for improved and/or new measures. In section 6 we discuss general methodological issues regarding data collection. Section 7 provides a brief summary and conclusion.

It may be helpful to briefly preview our principal recommendations concerning data collection. There are two general methods for collecting data on institutions such as those related to social dialogue. One is to have an expert create scores based on available quantitative and qualitative data taken from the secondary literature and from primary data collected mainly from interest group associations. The second is to use a detailed standardized questionnaire filled out by country experts, with their responses validated by comparing them with the existing literature and with discrepancies resolved via discussion with the experts. We believe the latter is preferable for the creation of a useful database on social dialogue. We also strongly recommend that indicators for which data are collected be as narrow as possible. The less aggregated each single measure is, the less ambiguous it is. Hence the higher is the validity of cross-country comparisons and the better traceable are developments over time. Such simple indicators can then be used to build more aggregated ones. 


\section{Associational Structure}

\section{Concepts and Their Uses}

There are three chief dimensions to interest group organization ${ }^{3}$ : density, concentration, and centralization. And there are two principal interest groups of concern: labor and business. Until relatively recently the bulk of attention with respect to interest group associational structure was focused on unionization. A large amount of research has examined the impact of union density on socioeconomic performance outcomes (for references see Kenworthy 1995, chap. 5; Kittel 2000b; Mishel and Voos 1992). One view holds that unions undermine economic efficiency by blocking the introduction of new technology, disrupting the market for labor, and driving wages above marginal productivity levels (Hayek 1960, chap. 18; Hirsch 1992; Troy, Koeller, and Sheflin 1980). Another contends that unions augment efficiency by replacing exit with voice as the principal means for workers to communicate their preferences to employers, and that encompassing unions in particular internalize the adverse effects of militant wage bargaining and are therefore likely to restrain wage demands (Freeman and Medoff 1984; Olson 1982). Of course, the behavior and effects of unions, and of their employer counterparts, are determined not only by membership density but also by their organizational concentration and centralization (see, e.g., Cameron 1984; Golden 1993).

\section{Measures}

\section{Density}

Union density is a measure of the power a trade union is able to generate. It is defined as the share of employed workers who are member of a trade union. Most researchers now refer to the data set on union density created by Ebbinghaus and Visser (2000), which is the best available approximation because its measures are corrected for the number of retired workers.

\section{Concentration}

Schmitter (1981) and Cameron (1984) each created relatively subjective and time-invariant measures of union concentration and centralization, drawing in part on Headey's (1970) earlier work. More recently, Golden, Lange and Wallerstein (1997, hereafter "GLW") and Traxler, Blaschke and Kittel (2001, hereafter "TBK") have created a set of more refined, objective, time-varying measures. We focus on these latter.

Union concentration (sometimes referred to as associational monopoly) has two basic aspects: across confederations (interassociational) and within confederations (intra-associational). The former refers to the extent to which union members belong to a single confederation rather than being divided among multiple confederations (or not belonging to any confederation). The latter refers to the extent to which the membership of the union confederation(s) is concentrated within a small number of affiliates rather than being spread out across a large number of affiliates.

\footnotetext{
3 Philippe Schmitter, who instigated the modern renaissance of interest in corporatism in the mid-1970s (Schmitte 1974), conceptualized corporatism as a mode of interest group organization ("interest intermediation").
} 
For measuring interassociational union concentration the GLW (1997) data set includes information on the share of union members that are members of each of the eight largest union confederations (and, with retired members excluded, each of the three largest). From these data Golden, Lange and Wallerstein calculate a Herfindahl index of concentration across all of the eight largest confederations. They also have data on the share of union members that are members of any confederation. For measuring intra-associational union concentration the GLW data set includes information on the number of affiliates in each of the four largest confederations and membership in the three largest of those affiliates. From these figures they calculate an approximate Herfindahl index for affiliates of each of the four largest confederations and for those four together.

Traxler, Blaschke and Kittel (2001) focus on three related but different measures of interassociational concentration: (1) the number of union confederations ("national, interindustry peak organizations"); (2) the share of the largest confederation in a country's total membership; (3) the share of unions unaffiliated to any union peak. (The third is of course a measure of fragmentation, rather than concentration.) For intra-associational concentration TBK focus on two measures: (1) the total number of unions affiliated to the largest peak; (2) the share of the three largest affiliates in their peak's total membership.

The GLW and TBK data on union concentration differ despite their very similar concept because Traxler, Blaschke and Kittel restrict the number of peak associations by requiring that their domain must conform to two conditions: territorial coverage must be national and branch coverage must be inter-industry, which is understood as comprising at least two complete onedigit ISIC sectors (Traxler, Blaschke and Kittel 2001, p. 39).

Neither Schmitter nor Cameron nor Golden, Lange, and Wallerstein offer measures of employer concentration. Traxler, Blaschke and Kittel have gathered data for one measure of interassociational employer concentration and one of intra-associational concentration. The former is the number of national, interindustry peak employer organizations. The latter is the number of direct affiliates of the largest employer peak organization. Little information is available about the share of the largest peak employer confederation in the aggregate membership of a country's employer associations or about the share of the largest affiliates in their peak's total membership (Traxler, Blaschke and Kittel 2001, p. 53); hence, TBK do not create measures for these.

\section{Centralization}

Union centralization refers to the authority that union confederations have over their members. This may vary, of course, depending on the issue or arena. Golden, Lange and Wallerstein provide data on various powers or capacities of each of the two largest union confederations: (1) to appoint affiliates; (2) to veto wage agreements by affiliates; (3) to veto strikes; (4) to have its own strike funds. Kenworthy (2000) has created a composite centralization index by assigning a score of 1 for the presence of each of these powers held by the largest confederation and summing them. The GLW data set also includes information on these powers/capacities (plus participation in enterprise-level bargaining) of the largest affiliate of each of the two largest confederations.

Traxler, Blaschke and Kittel have created a more thorough and detailed set of aggregate centralization measures. Specifically, they provide three union centralization measures, each based on a set of powers/capacities of a particular higher level vis-à-vis a particular lower level: (1) The first has to do with the formal powers/obligations of the largest peak union confederation vis-à-vis its direct affiliates. These are contingent on its right to (a) conclude collective agreements on its affiliates; (b) receive a share in dues collected by affiliates; (c) have its own strike fund; (d) veto collective agreements signed by affiliates; (e) veto strikes by 
affiliates; (e) participate in demand formulation and/or bargaining of affiliates; (f) obligation to submit the ratification of collective agreements to a membership ballot. Each of these is scored 0 for absent and 1 for present (except for (f), which is scored the opposite), and the scores are summed. (2) The second is an analogous measure of the formal powers/obligations of the largest peak's affiliates in relation to lower associational levels. (3) The third refers to formal associational control over the lowest level under the largest peak's umbrella, which decreases when representatives at the latter level are entitled to (a) organize strikes, (b) control their own strike fund, and (c) conclude collective agreements; such control increases when (d) they are formally guaranteed representation on that union body conducting collective bargaining at the higher level. TBK also create a composite union centralization indicator from these three measures, with each standardized to range from 0 to 1.

Employer centralization is measured by Golden, Lange, and Wallerstein using a set of indicators analogous to those they use for union centralization, though only for the largest confederation and the largest affiliate of that confederation. Once again Kenworthy (2000) has created a composite centralization index based on these indicators. ${ }^{4}$ Similarly, Traxler, Blaschke, and Kittel offer a set of centralization indicators that parallel their measures of union centralization.

\section{Recommendations for Data Collection}

In our view union density is best measured, following Ebbinghaus and Visser (2000), as nonretired union members as a percentage of the labor force. We are somewhat agnostic regarding which particular measures to use for interest group concentration and centralization. For concentration, if a single measure (of inter- and/or intra-associational concentration) is desired, a Herfindahl index is probably preferable. If multiple measures are acceptable, those of Traxler, Blaschke and Kittel seem suitable. For centralization, the composite measure created by Traxler, Blaschke and Kittel strikes us as the best. As we stress throughout this report, the key for any such measures is that the underlying data - number of confederations, share of union members that belong to each, power and obligations of peak associations, and so on - be collected in as narrow and detailed a fashion as possible, thereby maximizing flexibility in the construction of aggregated indicators.

\section{Wage-Setting Arrangements ${ }^{5}$}

\section{Concepts and Their Uses}

Wage setting or bargaining arrangements have always been prominent in the social dialogue literature, as wage formation is one of the areas in which organized interest groups have been most extensively and regularly involved in decision making. The predominant notion in this literature has been that centralized or coordinated wage setting yields low unemployment by engendering moderate rates of real labor cost (wages plus benefits adjusted for productivity and inflation) increase. The general logic is relatively simple, though specific applications of it can be complex (see, e.g., Franzese 1999; OECD 1997). If employees bargain aggressively for high wage increases and employers acquiesce, the latter can do five main things in response: raise productivity, raise prices, reduce profits paid out to investors, reduce investment, and/or reduce the number of employees. Where wages are bargained at a large number of separate firms or plants, each individual union may reasonably hope that its employer's response to a pay increase will consist predominantly of some combination of the first four options. None of these

\footnotetext{
${ }^{4}$ A similar measure has been created by Swank and Martin (2001).

${ }^{5}$ This section draws heavily on Kenworthy (2001b).
} 
responses will necessarily have an adverse short-term effect on employment or (inflationadjusted) wages, which are the principal concerns of union negotiators. Even if the firm chooses to reduce employment, those laid off should be able to find work elsewhere as long as the pattern of wage increases and layoffs is not generalized throughout the economy. Thus, where bargaining is decentralized and uncoordinated, there is an incentive for unions to pursue a strategy of wage militancy.

If the wage negotiations cover a relatively large share of the workforce, by contrast, union bargainers can be reasonably sure that a large wage increase will have an adverse impact on their members. A reduction in employment at a single firm does not necessarily reduce job prospects for those who get laid off. But if wage increases and ensuing layoffs are economywide, clearly employment opportunities will diminish. Centralized or coordinated wage setting thus generates an incentive for wage moderation.

Many researchers have assumed a linear relationship between wage setting centralization or coordination and unemployment. However, some have proposed that the effect is hump-shaped (Calmfors and Driffill 1988) or interactive with central bank independence (Hall and Franzese 1998), left government (Garrett 1998), union density (Kittel 2000b), or public sector union density (Garrett and Way 1999). Others hypothesize that the effect is both hump-shaped and interactive with central bank independence or the monetary regime (Culierman and Lippi 1999; Iversen 1999).

\section{Measures}

\section{Wage Centralization}

Wage centralization refers to the level(s) at which wages are bargained or set. Three principal elements must be considered in determining the degree of centralization in a given countryyear. The first is the level itself. Three tend to be most salient: peak/central/intersectoral, sector/industry, and company/plant. The second is the share of the work force for which wages are determined at each level. If a central wage agreement covers only $10 \%$ of the work force, it hardly makes sense to consider the wage bargaining process highly centralized. The third is the degree of "horizontal" centralization. In Britain, craft unions have traditionally negotiated wages for small groups of employees within a firm or plant, whereas in Japan most unions cover all employees within a plant or company. Bargaining is decentralized in both Britain and Japan, but arguably more so in the former because of this horizontal split. Similarly, in Sweden during the 1970s wages were negotiated mainly at the peak level. However, they were often bargained separately by one peak organization representing private-sector blue-collar workers (LO) and another representing private-sector white-collar and professional workers (PTK). Where bargaining is mainly at the sectoral level, the degree of horizontal centralization depends in part on the number of union and employer organizations and the degree of concentration among them.

Early measures created by Cameron (1984) and Calmfors and Driffill (1988) were the most influential in research by political scientists and economists through the 1980s and 1990s. A relatively recent OECD $(1994,1997)$ wage centralization measure now appears to be the most widely used.

Five newer indicators have been developed: three by Golden, Lange and Wallerstein (1997), a fourth by Iversen (1999), and a fifth by Traxler, Blaschke and Kittel (2001). These five measures improve on those of Cameron, Calmfors and Driffill, and the OECD in two respects. First, the Cameron and Calmfors-Driffill measures are time-invariant, and the OECD measure is available only for 1980, 1990, and 1994. The GLW, Iversen, and TBK indicators vary over time and are measured annually. This is a beneficial development, as wage-setting arrangements have changed quite a bit over time in some countries. Moreover, the impact of 
wage setting may vary across different periods (Kenworthy 1996, 2002; Traxler, Blaschke and Kittel 2001). If a time-invariant measure is used in analyses, it is impossible to know whether a finding of period-specific effects owes to changes in the effects of wage setting or to (unmeasured) changes in the wage-setting arrangements themselves. Second, the GLW, Iversen, and TBK measures tend to be grounded in more and better data. Available data on the details of wage setting in specific national contexts are much more extensive now than was true a decade or two ago, and in several cases those data have been gathered by the creators of the wage-setting measures themselves.

Each of the Golden-Lange-Wallerstein indicators is a measure of centralizing activities or efforts by relevant actors, rather than of the degree of wage centralization per se. The first is an index of involvement in wage bargaining by peak-level union and employer confederations. The scores range from 1 to 11, with the lowest score representing complete lack of involvement and the highest indicating that the confederations negotiate a central wage agreement with limits on supplementary bargaining.

The second GLW measure is an index of government involvement in the wage-setting process. The scores range from 1 to 15 , with the lowest score indicating that government is entirely uninvolved and the highest referring to government imposition of a wage freeze with a prohibition on supplementary local bargaining. Forms of state intervention that fall between these extremes include, among others, the provision of economic forecasts to bargaining partners, imposition of a cost-of-living adjustment, and imposition of a national wage schedule by a government arbitrator.

The third GLW measure is a summary index of the overall degree of wage centralization. This indicator is scored from 1 to 4 . Centralization can result either from bargaining by peak-level interest group associations or from government intervention, or from both. Thus, Golden, Lange and Wallerstein combine their first two indicators to yield the third. The GLW overall centralization index is the only existing indicator that explicitly focuses on the centralization of wage setting by taking into account situations in which there is government-imposed centralization. Others are measures of the centralization of wage bargaining. For researchers attempting to explèain wage restraint, the inclusion of government involvement may be theoretically preferable, since in many instances government intervention is aimed at encouraging or mandating such restraint. If the interest is in explaining wage inequality, on the other hand, it may be preferable to use a centralization measure that excludes government intervention, since in many cases such intervention does not aim to affect the distribution of wages. Minimum wage laws are an obvious exception, but they are scored by GLW as the weakest form of government involvement.

In our view, the Iversen and TBK indicators are the best existing bargaining centralization measures. Like the GLW confederation involvement measure, these two improve on prior measures in featuring annual measurement and being better grounded in objective data. Unlike the GLW measure, they focus on the degree of centralization itself rather than the extent of centralization-related activities by confederations. And their construction makes them almost certainly more valid than earlier measures. The key difference between the two is that Iversen's measure focuses on the structural characteristics of the wage bargaining process whereas the TBK measure treats centralization as a behavioral concept. Iversen's measure seeks to identify the degree to which wage-bargaining arrangements are centralized. The TBK measure seeks to capture the degree to which bargaining itself is centralized.

Iversen's indicator is based on the locus of bargaining authority and the degree of concentration of union membership. It aims to measure "organizational centralization," rather than the degree to which wages actually end up being set at higher levels (Iversen 1999, p. 49). A score ranging from 0 to 1 is assigned for each of the three main bargaining levels: centralized, intermediate, and decentralized. The scores for the three levels sum to 1, with the score for each level based on the bargaining rights accorded that level. The scores are (Iversen 1999, pp. 84-85): 
0, 0.1, 0.9 Plant- and firm-level bargaining predominates with some elements of industrylevel bargaining.

0.1, $0,0.9$ National associations and the government set nonenforceable targets for plant-level bargaining, but local organizations retain rights to bargain and to call strikes or lockouts.

0, 0.8, 0.2 Industry-level organizations monopolize bargaining and strike/lockout decisions, and agreements are enforceable. Local bargaining is permitted subject to a peace clause.

0.1, 0.7, 0.2 National associations and/or the government set nonenforceable targets for lowerlevel bargaining, but industry-level organizations retain rights to bargain enforceable agreements. Local bargaining is permitted subject to a peace clause.

0.5, 0.3, 0.2 National associations negotiate central agreements with some capacity for enforceability, but industry-level organizations retain the right to bargain separate agreements without adherence to a peace clause.

0.8, 0, 0.2 National associations monopolize bargaining, and agreements are enforceable. Local bargaining is permitted subject to a peace clause.

0.9, 0, 0.1 National associations monopolize wage bargaining, and agreements are enforceable. Lower-level bargaining is banned.

Each of the three scores is then weighted by an index of union concentration at that bargaining level. The three weighted scores are then combined (using the formula shown in the Appendix) to create the centralization score.

Notice that a number of Iversen's categories for coding the level of bargaining are based partly on whether or not there is a "peace clause" governing lower-level bargaining. A peace clause (or peace obligation, as it is sometimes called) is a type of sanction that prohibits strikes and lockouts at lower levels. It thereby forecloses one strategy through which lower-level bargainers may attempt to circumvent central- or industry-level wage agreements. However, by no means does it eliminate the ability of company- or plant-level bargainers to reach separate agreements. Peak-level settlements in Sweden and Norway in the 1970s included a peace obligation, yet agreements reached at lower levels accounted for $30 \%$ to $60 \%$ of total wage increases during that decade (Flanagan 1990, p. 398; Traxler, Blaschke and Kittel 2001, p 127). This reliance on the presence or absence of a peace obligation as a key for coding decisions is indicative of how Iversen's measure focuses on structural features of the wage bargaining process (institutions) rather than on the level(s) at which wages are actually bargained or set (behavior).

One drawback of Iversen's measure is that it does not take into account the share of the workforce covered by wage bargaining at each level. A union at a particular level may organize a low percentage of workers directly and yet, because of extension clauses, influence the wages for a much greater percentage. To compensate for this measurement deficiency, which characterizes almost all centralization indicators, some analyses of effects of wage centralization include the overall coverage rate as a separate variable in their regression models (OECD 1997). However, the key for an accurate measure of wage centralization is coverage at each particular level of bargaining, not the overall rate of coverage.

The TBK measure is based solely on behavior. That is, it focuses on the actual level(s) at which bargaining takes place, rather than the bargaining authority of each level, and it takes into account the actual degree of influence that lower-level bargaining has on final wage outcomes, rather than relying on the presence or absence of a peace clause as a proxy for that influence. ${ }^{6}$ The TBK measure also incorporates the share of workers covered at each bargaining level.

${ }^{6}$ Traxler, Blaschke and Kittel (2001, p. 184) have also created a separate, dichotomous indicator of "bargaining governability," which refers to the presence or absence of legal sanctions on lower-level bargaining. 
They assign a centralization score based on their case-by-case judgment regarding the appropriate mix of the importance of each bargaining level (in terms of its effect on wages) and the coverage rate at each level, with a heavier weight generally attached to the latter (Traxler, Blaschke and Kittel 2001, pp. 112-13). The "horizontal" dimension of centralization is also included in the TBK measure. They assign a higher centralization score if bargaining at a given level occurs for all groups of workers jointly than if it is group-specific. The scores for the TBK measure are as follows (Traxler, Blaschke and Kittel 2001, p. 307; we have reversed the scores so that higher values indicate greater centralization):

1 Company and plant, with group-specific bargaining.

1.5 Company and plant, with all groups and group-specific bargaining equally important.

2 Company and plant, with all groups bargaining jointly.

3 Combination of industry and company and plant, with group-specific bargaining.

3.5 Combination of industry and company and plant, with all groups and group-specific bargaining equally important.

4 Combination of industry and company and plant, with all groups bargaining jointly.

5 Industry, with group-specific bargaining.

6 Industry, with all groups bargaining jointly.

7 Combination of central, industry, company, and plant, with group-specific bargaining.

7.58 Combination of central, industry, company, and plant, with all groups bargaining jointly at the central level and group-specific bargaining at all other levels.

8 Combination of central, industry, company, and plant, with all groups bargaining jointly.

9 Central and industry, with group-specific bargaining.

10 Central and industry, with all groups bargaining jointly.

11 Central, with group-specific bargaining.

12 Central, with all employees bargaining jointly.

A drawback of the Traxler-Blaschke-Kittel measure is its heavy reliance on subjective judgment. Reliability would likely be increased if the index could be based on an explicit formula, as is Iversen's. TBK suggest that combining the three elements of centralization - the bargaining level(s), the coverage rate at each level, and the degree of horizontal centralization does not yield a consistent ranking (Traxler, Blaschke and Kittel 2001, p. 112). Since a formula-based ranking implies a need to make difficult theoretical choices in devising such a formula, they claim that a consistent ordinal measure of coordination across countries cannot be created in practice. Although case-by-case judgment is not preferable per se, they argue that it is the best approximation given the current conceptual difficulties. Then too, in some instances application of a pre-set formula might lead to very misleading results. Substantial wage increases may be bargained at the plant level but anticipated and adjusted for at a higher bargaining level. The higher level may therefore be the most important source of wage outcomes even though the formal share of wage changes for which it accounts is fairly small (Hibbs and Locking 1996).

The principal use of wage centralization measures has been as a predictor of macroeconomic performance. One could argue that a structural measure should be preferred in such analyses because structure is causally prior to behavior. On the other hand, using a structural measure to predict macroeconomic performance presumes that the centralization of wage bargaining arrangements determines wage-setting behavior, which in turn determines wage (labor cost) 
changes, which in turn determines macroeconomic outcomes. Two links in the causal chain, in other words, are assumed. Using a behavioral measure of centralization has the advantage of closing one gap in the hypothesized causal sequence. There seems no compelling a priori reason to favor either a measure based on wage bargaining structures or one based on wage bargaining behavior. It depends on the researcher's theoretical interest.

\section{Wage Coordination}

In an influential article, David Soskice (1990) argued that the focus of analysts interested in effects of wage setting should be on coordination rather than centralization. The degree of coordination in the wage-setting process is likely to greatly influence wage outcomes, he suggested, and bargaining centralization is only one means (albeit an important one) of achieving such coordination. A second is state-imposed centralization, as in Belgium, the Netherlands, and Denmark in some years and even Canada and the United States in a few. A third is intra-associational coordination, which involves guidance of industry or firm-level bargaining by peak union and/or employer confederations, as in Switzerland, Austria prior to the mid-1980s, Norway in a number of years, the Netherlands since 1983, and Italy since 1993. A fourth means of achieving coordination is pattern-setting led by a powerful sector, as in Germany, or by a group of influential firms, as in Japan.

Wage coordination is fundamentally a behavioral concept. It refers to the degree of intentional harmony in the wage-setting process - or, put another way, the degree to which minor players deliberately follow along with what the major players decide. "Major" players include, for example, peak-level union and employer confederations in countries such as Norway and pre1983 Sweden, the metalworkers union and its employer counterpart in Germany, and a set of influential large firms in Japan.

Coordination was the focus of Colin Crouch's (1985) dichotomous indicator of "industrial relations systems," which in turn drew on a classification created nearly 20 years earlier by Anne Romanis. Soskice himself offered coordination scores, though for only 11 countries. The Soskice scores have been updated and extended to a larger set of nations by Richard Layard, Stephen Nickell and Richard Jackman and more recently by Peter Hall and Robert Franzese. In addition, the OECD has created a coordination counterpart to its centralization measure.

As best we can tell, each of these indicators attempts to score countries based on the degree of intentional harmonization observed in the wage-setting process. This is a relatively heroic exercise. In practice it is not easy to measure the actual degree to which the various actors involved in the wage-setting process deliberately harmonize their bargaining. To do so in an accurate fashion, the researcher must factor in both the share of the work force whose wages are deliberately pegged to the agreement(s) reached by the major player(s) and the degree to which minor players follow along (i.e., how closely they adhere). It is not clear exactly how Soskice decided that, for instance, the degree of harmonization in Sweden exceeded that in Germany. We suspect Soskice's scores were based on an impressionistic reading of the degree to which minor players follow along with major-player decisions coupled with intuition about the degree to which the wage-setting institutions in each particular country are likely to (rather than actually do) generate coordination. The Layard-Nickell-Jackman, Hall-Franzese, and OECD coordination indicators appear to follow Soskice's measurement strategy, though it is difficult to know for certain because no explicit rationale is provided for their coding schemes. Plainly, there is potential for significant measurement error in such indicators.

Could one instead use a wage-setting outcome, such as the degree of wage restraint, as the basis for measuring the degree of coordination in each country? Information on this is certainly easier to obtain and much more straightforward to rank. But the answer is no, for two reasons. First, this would render the measure useless - because tautological - for the purpose of attempting to explain wage restraint, which has indeed been one of the principal uses of wage coordination measures. Second, and more important, coordination of wages and restraint of wages are distinct phenomena. For instance, a wage-setting process that is effectively centralized, for instance, should be considered highly coordinated even if the central agreement yields 
extremely high pay increases, provided that bargainers at lower levels do not alter the central agreement excessively. Similarly, wage setting in Germany should be considered relatively coordinated even if the metalworkers union successfully negotiates a $30 \%$ wage increase in a given year, as long as other industries, firms, and plants more or less follow suit. Nor does wage restraint necessarily imply coordination. Pay increases are uniformly low in the United States in some years, but there is little intentional harmonization of wage settlements across companies. Wage coordination also does not imply that all or most workers get the same rate of pay increase. Consider again a prototypical centralized case. The peak-level settlement could specify that chemical workers get a $20 \%$ wage increase while hotel employees get a $2 \%$ increase. As long as lower-level bargainers follow along, wage setting should be considered coordinated. Wage restraint and/or compression may be more likely in countries with a high degree of wage coordination, but neither is presupposed by the concept itself.

An alternative strategy for measuring wage coordination is to focus on coordinating activities by the major player(s), rather than on the degree of coordination actually achieved. Traxler, Blaschke and Kittel (2001, chap. 10) have done this. Since these activities, or "modes of coordination," are qualitatively different from one another, TBK create a categorical coordination indicator. They identify six principal modes of coordination:

- Inter-associational coordination by the peaks of unions and employer associations (classic bargaining centralization)

- Intra-associational coordination by the peaks (as in Austria and Switzerland), i.e., imposition of coordination within either the major trade union association or the major employers' association within coordination between the union and employer peaks

- Pattern bargaining

- State-sponsored coordination (bargaining centralization that includes formal participation by government representatives)

- State-imposed coordination

- Uncoordinated bargaining.

TBK code their coordination scores based on activities by major players that are aimed at securing coordination, "regardless of whether these efforts were successful in terms of their coordination effects" (2001, p. 148). The one exception to this coding procedure is patternsetting, which does not necessarily require active harmonizing efforts by the pattern-setter(s). Nevertheless, it is relatively easy to identify the countries for which pattern-setting is the main coordination mode.

The chief disadvantage of this approach is that it ignores likely variation within each bargaining mode in the degree of coordination generated. What options are there for researchers who wish to focus on the degree, rather than the type, of coordination? One is to use one of the Soskicetype measures discussed above. Their chief drawback is that they are relatively impressionistic and therefore may suffer from nontrivial measurement error. An alternative is to create scores based on a set of expectations about which institutional features of wage-setting arrangements are likely to generate more or less coordination. This avoids the problem of limited information about the intentions of various actors in the wage-setting process and the difficulty in ranking such intentions even if such information were readily available. Such a variable has been created by Kenworthy (2001a), in the form of an index with five categories. The scores are as follows:

1 Fragmented wage bargaining, confined largely to individual firms or plants (Canada, Ireland 1960-69 and 1981-87, New Zealand since 1988, United Kingdom since 1980, United States)

2 Mixed industry- and firm-level bargaining, with little or no pattern-setting and relatively weak elements of government coordination such as setting of basic pay rate or wage indexation (Australia since 1992, France, Italy in most years) 
3 Industry-level bargaining with somewhat irregular and uncertain pattern-setting and only moderate union concentration (Denmark in most years since 1981, Finland in a few years, Sweden since 1994)

Government wage arbitration (Australia prior to 1981, New Zealand prior to 1988)

4 Centralized bargaining by peak confederation(s) or government imposition of a wage schedule/freeze, without a peace obligation (Belgium and Finland in most years, Ireland $1970-80$ and 1987-93)

Informal centralization of industry- and firm-level bargaining by peak associations (Italy since 1993, Netherlands since 1983, Norway in some years, Switzerland)

Extensive, regularized pattern-setting coupled with a high degree of union concentration (Germany, Austria since 1983)

5 Centralized bargaining by peak confederation(s) or government imposition of a wage schedule/freeze, with a peace obligation (Denmark 1960-80, Ireland in the 1990s, Norway in some years, Sweden 1960-82)

Informal centralization of industry-level bargaining by a powerful, monopolistic union confederation (Austria prior to 1983)

Extensive, regularized pattern-setting and highly synchronized bargaining coupled with coordination of bargaining by influential large firms (Japan).

Note, however, that this variable is not a measure of wage coordination per se. It is, instead, a hypothesis or prediction about the degree of coordination that is likely to be generated by various wage-setting institutions. It is similar to Iversen's centralization measure in focusing strictly on institutional features. The difference is that, because his indicator is based on organizational authority and union concentration, Iversen is able to rank wage bargaining arrangements more or less unambiguously in terms of their degree of centralization. That is impossible to do for coordination, because coordination is generated by qualitatively different institutional arrangements.

Some researchers may be interested in the effects of wage coordination but skeptical about the reliability of existing scale measures and uncomfortable with an index based on structural characteristics. A variety of alternative strategies for operationalization exist. One option, employed by Traxler and Kittel (2000) in their analysis of the impact of wage-setting arrangements on wage restraint and macroeconomic performance, is to use a set of dummy variables representing various modes of coordination (combined with degrees of bargaining governability, which refers to the presence or absence of coordination-fostering legal framework conditions: legal enforcement of central agreements vis-à-vis affiliates and a peace clause during the term of a contract). An alternative would be to use a scale indicator of bargaining centralization (such as the Iversen or Traxler-Blaschke-Kittel measure) and three dummy variables: one representing informal centralization, a second representing patternsetting, and a third representing state-imposed centralization (with uncoordinated bargaining as the omitted category). Other options are obviously possible.

\section{Recommendations for Data Collection}

It has been fairly common among researchers interested in the effects of wage restraint on macroeconomic performance to use measures of the structural characteristics of union and/or employer associations - e.g., union centralization or concentration - in their analyses (e.g., Bruno and Sachs 1985; Garrett and Way 1999; Golden 1993; Headey 1970; Kenworthy 1996). When the theoretical interest is in the effects of organizational encompassingness (Olson 1982) rather than of wage setting per se, the use of this type of indicator may be perfectly appropriate. However, measures of interest group organization should not be used as proxies for wage centralization or coordination. A high level of union (or employer) centralization and/or concentration by no means guarantees that the wage setting process itself will be centralized or coordinated. For instance, union centralization and concentration remained relatively stable in Sweden through the 1970s and 1980s (Lange, Wallerstein and 
Golden 1995, pp. 80-87), yet bargaining centralization in Sweden declined in the 1980s. Union concentration has been perhaps the most commonly used indicator of organizational structure. Kenworthy (2001b) reports that the correlations between the Golden-Lange-Wallerstein measure of intra-associational concentration and 14 measures of wage centralization and concentration, using 1974-89 period averages, is only .27. For interassociational concentration the correlation with those 14 measures is -.16.

For wage centralization we recommend creation of both a structural measure and a behavioral one. Although the two are likely to be somewhat similar, there are critical conceptual differences. Moreover, the best existing measures of these two types - those of Iversen and Traxler-Blaschke-Kittel, respectively - correlate at only .66 across the 16 OECD countries and 20 years for which both measures are available. Both should incorporate the share of the workforce covered by wage bargaining at each of the three main levels and the degree to which bargaining at a given level occurs for all groups of workers jointly or is group-specific. A structural indicator should add the bargaining rights accorded to each bargaining level, whereas a behavioral indicator should add the actual degree of influence that lower-level bargaining has on final wage outcomes. It would also be helpful to have information on government intervention into the wage determination process in order to construct a measure of centralization of wage setting (rather than bargaining), although for the creation of a flexible database it is preferable to collect this information separately.

For wage coordination we recommend a measure of coordination mode along the lines of that created by Traxler, Blaschke and Kittel. The data required for accurate coding of a Soskice-type measure capturing the actual degree of coordination are virtually impossible to obtain, and the Kenworthy variable described above is not a measure per se.

\section{Participation in Public Policy}

\section{Concepts and Their Uses}

Endeavors to measure the extent of participation of interest associations have their roots in two strands of the analysis of the linkages between the state and the economy. First, in the public choice literature interest associations tend to be regarded as rent-seeking lobby organizations which attempt to influence public policy in favor of their constituency. Second, in the corporatist literature, cooperative arrangements between the government and encompassing interest associations are regarded as conducive to accelerated economic growth, low unemployment and low inflation. "Corporatist concertation," as participation of associations in public policy is called in this literature, is characterized by (a) a structural component stating that a limited number of organizations usually representing antagonistic interests has privileged access to policy making and (b) a behavioral component stating that they manage their conflicts and coordinate their action with that of government with a view to its economy-wide implications (Lehmbruch 1984, p. 62).

The two approaches expect different outcomes of interest group participation in public policy making. The rent-seeking perspective regards the influence of associations as detrimental to the "public good" because both the attempts at gaining influence and the rent-creating policies induced by special interest groups result in inefficiencies. In contrast, the corporatist literature argues that the representation of interest associations in public policy making contributes to a more reflective and balanced mode of policy making based on mutual trust, which leads to greater long-term efficiency. This holds in particular for encompassing associations. In practice, elements of both perspectives can be expected to be relevant. While it is a truism at least since Olson's (1982) contribution that encompassing organizations tend to be more oriented toward economy-wide performance criteria, we should expect that there is no deterministic association between structural characteristics and behavior. Further, the organizational structure of associations is an important institutional precondition of their behavior. 
These two propositions have spurred a large number of analyses, in which various researchers have attempted to assess the extent of associational participation in or influence on policy making. However, quantitative approaches using indicators of associational influence in order to make cross-country comparisons have been limited, in particular in comparison to the large quantitative literature on wage setting.

At the conceptual level, we distinguish four approaches to measuring associational participation in and/or influence on public policy making. First, in many contributions to the public choice debate, Olson's proposition that with increasing length of a democratic regime associations obtain a firmer grip on policy making has been taken for granted, and the number of years since the establishment of democracy is considered a valid approximate measure of associational influence (Nardinelli, Wallace and Warner 1987; Olson 1982; Weede 1996). We do not deal with this proposition here because - in addition to doubt about its conceptual validity - this approach does not involve any research into the mechanisms of associational participation/influence.

Second, an indirect approach has been taken by a number of scholars who proposed an interactive hypothesis on the conditional effect of government partisanship and labor power (Lange and Garrett 1985; Scharpf 1991). According to these authors, a trust relation built up between social democratic parties and powerful - encompassing and centralized - trade unions allows them to embark on long-term growth policies which improve economic performance. In contrast, conservative parties in government fit well with powerless trade unions because the latter are unable to distort market processes, leading to market-led economic growth. The other two combinations imply either an antagonistic constellation or lack of coordinative capacity on the side of labor, which are both regarded as detrimental to growth. In this approach, associational influence is assumed to be a function of associational power and the willingness of the government to let associations participate, which again is assumed to be a function of its ideological position. In this approach, no direct measures of associational influence are needed since structural attributes of trade unions and the partisan composition of the government suffice. A newer variant of this approach with a somewhat adjusted theoretical background analyzes the conditional effect of central bank independence and wage bargaining centralization (Cukierman and Lippi 1999; Hall and Franzese 1998; Iversen 1999). Here again, no measures of associational influence are required, because the core proposition is an interactive effect of state structure (independence of the central bank) and wage bargaining institutions (centralization) without reference to a direct link between associations and the government.

Third, a variety of contributions to the debate have made use of synthetic indices. Claiming that associational influence on public policy is a multifaceted concept, they combine various measures into an overall index measuring the extent of, e.g., "corporatism" (Lijphart and Crepaz 1991), "institutionalized cooperation" (Hicks and Kenworthy 1998), or "economic integration" (Siaroff 1999). Since these concepts are meant to capture an overall assessment of associational influence, we will discuss their measurement in more detail below.

Fourth, a handful of studies have attempted to explicitly and directly address the influence of associations on policy making (Boreham and Compston 1992; Compston 1997; Traxler, Blaschke and Kittel 2001). Instead of combining several dimensions into a synthetic index, these authors stress the different logics of policy concertation and wage coordination. In consequence, they argue, the operationalization of associational influence should not be conflated with wage bargaining but handled as a distinct dimension of associational behavior. 


\section{Measures}

Given that only the third and fourth approaches attempt to assess policy concertation directly, we restrict our detailed discussion of the various choices regarding operationalization to these two.

\section{Synthetic Indices}

During the 1980s, various indices of corporatism have been discussed which are largely based on a qualitative assessment by the author. Perhaps the most influential one was the grouping of countries according to the extent of policy concertation by Lehmbruch (1984, pp. 65-66), who built a 4-point scale ranging from pluralism to weak and medium corporatism to strong corporatism and added as a fifth group the category "concertation without labor." This and eleven other expert classifications have been combined into an average score by Lijphart and Crepaz (1991) in order to obtain a summary measure of corporatism. Unfortunately, this approach does not take into account the differing conceptual focus of the various classifications (Keman and Pennings 1995, pp. 271-273) and hence is of limited usefulness for empirical work aiming at policy concertation.

Also in a factor-analytic framework, Hicks and Kenworthy (1998) construct a two-dimensional index of cooperative institutions, referring to neocorporatism and firm-level cooperation. According to this approach, the neocorporatist dimension is constituted by high factor loadings of the existence of business confederations, coordinated wage bargaining, two indices of "tripartite neocorporatism," cooperation between government and interest groups, long-term relationships between investors and firms, and cooperation between labor and management (Hicks and Kenworthy 1998, p. 1646). The variable of interest here is cooperation between government and interest groups. It is a 3-point scale of the degree of cooperation based on a qualitative assessment that differentiates between "relatively cooperative interaction between cohesive government agencies and coordinated business and labor organizations," "moderate cooperation," and "relatively combative, conflictual relationship[s] between fragmented state agencies and interest group organizations" (Hicks and Kenworthy 1998, p. 1663).

Finally, the most comprehensive synthetic index has been developed by Siaroff (1999). ${ }^{7} \mathrm{He}$ proposes to replace the term corporatism by integration, which he defines as "a long-term cooperative pattern of shared economic management involving the social partners and existing at various levels such as plant-level management, sectoral wage bargaining, and joint shaping of national policies in competitiveness-related matters (education, social policy, etc.)" (Siaroff 1999, p. 189). The index is an average of three indicators of social partnership (strike volume, nature and goal of trade union, legal and state support for union and union power), two indicators of industry-level coordination (nature of economic ties and outlook of firms, extent of co-determination in the workplace), and three indicators of overall national policy-making patterns (nature of (conflict resolution in) national industrial adjustment and wage setting, extent of "generalized political exchange" in industrial relations and national policymaking, general nature of public-private interaction), which are all ranked on a five-point scale (Siaroff 1999, pp. 189-194).

\footnotetext{
${ }^{7}$ This article also provides the most comprehensive overview of indicators of corporatism available at that time.
} 
This last element directly addresses policy concertation. Siaroff constructs five-point scales for each of the dimensions and assigns a rank order to each country. The nature of conflict resolution focuses on the way in which the state and the labor market associations coordinate their policies, ranging from bargained to statist. The measure of generalized political exchange ranges from extensive exchange to none. Finally, the general nature of public-private interaction is measured on a scale ranging from encompassing co-ordination to pluralism (Siaroff 1999, pp. 189-194). ${ }^{8}$

\section{Associational Participation/Influence}

The first systematic approach to assess associational participation/influence on public policy is an index developed by Boreham and Compston (1992, pp. 151-152), which is more thoroughly motivated by Compston (1994, 1995a, 1995b) and reanalyzed on a more extensive dataset by Compston (1997). It measures the extent of union participation in economic policy making, defined as "discussions at the national level (as opposed to the regional or sectoral levels) between government representatives and trade union officials about the formation of government policies relating to employment, prices, growth, and trade" (Compston 1997, p. 736). Hence the index refers to fiscal policy, monetary policy, investment, overall industrial planning, trade policy, job creation and training, and employment law. Since incomes policy represents "government participation in union policy making rather than union participation in government policy making" (Compston 1997, p. 736), this policy area is excluded from consideration. The concept also explicitly disregards discussions and agreements that are not made public, engagement of unions in policy implementation, and the accumulation of trade union and government functions by individuals which gives trade unionists a direct say in policy making. The scale is roughly divided into a five-point ranking, ranging from no participation (0), narrow consultation (1-3), broad consultation (4-6), narrow agreement (7-8), to broad agreement (9-10). After being identified as belonging to one of these categories, the score for a country in a particular year is adjusted for the scope of economic policy covered within the range over which the category is defined.

Because this concept presents an overall characterization of the extent of union participation in public policy making, it remains at a rather general level. Two routes aiming at a refinement of the approach laid out by Boreham and Compston (1992) have been taken.

First, Traxler, Blaschke and Kittel (2001) have developed an index of associational participation in state regulation which starts from an assessment of the activities of the largest peak associations of trade unions and employers associations in specific policy areas and aggregates these into an index of participation by trade unions and employer organizations, respectively. The index draws from the following information (Traxler, Blaschke and Kittel 2001, p. 76):

General activities:

- Influence on the national government or parliamentary bodies with regard to labor market issues

- Representation of the members' labor market interests in national corporatist institutions

\footnotetext{
${ }^{8}$ A 'left corporatism' index referring to "long-term working class mobilization and political economic integration," which has been created by Hicks and Swank (1992, p. 671), is based on the country scores on one dimension of a factor analysis based on a variety of political institutions and other characteristics of the political system. High scores on this dimension are attained by union strength, union centralization, class mobilization and the number of years a left party was in office. As can be seen from this list, this indicator does not actually refer to associational participation but to a wider concept of corporatism which encompasses the combined economic and political power of the labor movement and is partly based on indicators discussed in section 1. A variant of this index is used by (Swank 2001).
} 
Specialized activities:

- Participation in the formulation of industrial policy programs, regional development programs, public occupational programs (including apprenticeship) and active labor market policy, research and development programs, quality control programs, and/or standardization of products

- Implementation or participation in the implementation of: industrial policy programs, regional development programs, public occupational programs (including apprenticeship) and active labor market policy, research and development programs, quality control programs, and/or standardization of products.

The coding of each single element of these categories is dichotomous; hence no information on the extent of influence beyond participation in formulation or implementation is available. For the aggregate index, the two general activities set the rough scale and the specialized activities (which are coded as 1 if the largest peak association engaged in that activity) add the finer differentiation. ${ }^{9}$ The resulting scale is then standardized to the $0-1$ interval (Traxler, Blaschke and Kittel 2001, pp. 309, 312).

A second route is pursued by Tálos and Kittel (2001). With a view to analyzing differences in the extent of social partnership between policy areas in Austria which classical concepts in the policy network literature cannot distinguish, they develop a scale of associational participation that focuses on the extent of participation and the scope of the actor constellations in policy making processes. The concept of participation is refined by differentiating between three layers of participation: "accordation," concertation, and involvement. This refinement is important because it transcends both the narrow operationalization of "participation" by "influence" - which the Compston $(1994,1995 a, 1995 b)$ indicator seems to measure in practice - and the dichotomous approach of Traxler, Blaschke and Kittel (2001). Accordation is a mode of policy making in which the state negotiates proposals with the peak associations of labor and capital and which results in a binding, though not necessarily public, agreement. Concertation is a mode in which intensive negotiations and bi- and tripartite talks take place that strongly influence the substantive results but that does not lead to a final agreement. Hence the role of the state is more pronounced. Involvement implies that the state discusses proposals with the peak associations without aiming at a joint opinion of all participants (Tálos and Kittel 2001, p. 75). The extent of participation is strongly correlated with the scope of the actor constellation, ranging from a closed constellation of actors with privileged access to a policy area to a fully open constellation with many interest groups involved. These concepts are the foundation of a scale of associational participation (Tálos and Kittel 2001, pp. 75-76):

1 No (formal) involvement of the peak associations in public policy making in a broader constellation

2 Formal involvement without relevant cooperation in a broader constellation

3 Formal involvement of the peak associations with relevant cooperation of either labor or capital in a broader constellation

4 Concertation between the state and the peak associations in a restricted constellation

5 Accordation between the state and one of the peak associations in a constellation with restricted access to the policy area

\footnotetext{
${ }^{9}$ More precisely, in the case of union participation, TBK consider eight different specialized activities, each of which scores one. In order (a) to emphasize the weight of the general activities and (b) to obtain an unambiguous ranking, each of the general activities scores nine, and all weighted scores are added. This yields a scale ranging from 0 to 26.
} 
6 Accordation between the state and the peak associations without accordation between the associations

7 Concertation and tripartite accordation between the peak associations and the state in a closed constellation

8 Bipartite accordation between the peak associations with state support in a closed constellation.

The ranking is used for categorizing the genesis of laws in different policy areas. This information is then aggregated into a time-varying characterization of the extent of associational participation in different policy areas.

\section{Recommendations for Data Collection}

In contrast to the wide variety of detailed measures of associational structure and wage-setting arrangements, there has not yet developed a generally accepted operational definition of associational participation/influence in policy formation. One important cause is that far less research in the field of quantitative comparative political economy has been devoted to participation in policy making from the perspective of the corporatist tradition. This may be related to the much more complex nature of policy formation. While wage bargaining focuses on a small set of issues in which a restricted number of actors is involved, policy formation covers practically all dimensions of collective decision making with various interests represented in different manners.

As an element of encompassing synthetic indices, the indicator referring to the mode of policy formation is usually rather impressionistic and vague, and the decision rules for the assignment of values to countries is intractable for other researchers. Hence measurement validity is problematic and the usefulness of such indices for the assessment of any particular aspect of corporatism, social partnership, or social dialogue is limited. Further, overall measures of associational participation for a country may stress different dimensions or areas of policy formation in each country. Therefore, we see the most promising approach for obtaining valid measures of associational influence in the attempts to directly address the extent of participation of associations in the policy-making process in specific policy areas. An ideal approach would combine the following perspectives: First, in order to establish a maximum of cross-country comparability, the measure should be broken down into particular policy areas. For each policy area, a separate evaluation of the extent of associational participation and influence should be made. Differentiation between important and less relevant decisions in a particular policy area would fine-tune the measure. Second, a scale should differentiate between different scopes of participation according to clear criteria, which allows for both within-country and betweencountry variation. A start has been made by separating the concept of participation into accordation, concertation, and involvement. Third, the measure should be constructed in a way that allows for variation in the time dimension. However, unlike wage bargaining, policy formation is not a process that has a defined beginning and end but one that occurs over an indeterminate length of time; hence it is difficult to develop a clear sequencing.

These criteria suggest that the optimal approach would be to establish criteria that are detailed enough - as detailed as possible - to allow for a clear presence/absence decision by the coder and which can then be aggregated according to the research tasks in question. Because of the complex nature of policy formation, flexibility is even more important than in the case of measures of associational structure or of wage setting. 


\section{Firm-Level Representation}

\section{Concepts and Their Uses}

A core element of theories of national economic success is the presence of trustful relationships between employers and employees. This fosters the ability of firms to embark on long-term strategies (Streeck 1992; Rogers and Streeck 1995). In this vein, cooperative firm-level arrangements between workers and employers are regarded as important conditions for the ability to upgrade products and processes, which is at the core of firm competitiveness. Since firm competitiveness, seen from a national perspective in a world-wide market, aggregates to national competitiveness, the analysis of the conditions of firm-level trust has important policy implications. From an aggregate perspective, the possibilities of the state and interest associations to foster firm competitiveness touch upon two dimensions. First, trust is both a result and a condition of firm-level cooperation. Second, it depends on the intensity of firmlevel distributional conflicts.

\section{Measures}

Among quantitative, cross-national studies of labor relations, firm-level worker representation has received only little attention. An early exception is Cameron's (1984, pp. 164-69) reference to the existence of firm-level representational bodies. The index of corporatism created by Bruno and Sachs (1985, p. 226) contains as an element the existence of works councils, albeit without further explanation. In the labor index created by Kenworthy (1995, pp. 120-123), the existence of works councils is considered as a supplement to trade union density.

The only comparative study of this style we are aware of proposing a specialized index focusing at the level of the firm is Kittel (2000a, pp. 199-200). Kittel constructs an index of institutionalized firm-level worker representation from three elements:

- Legal foundation (law, collective agreement between peak-level associations, firmlevel agreement)

- Legally founded rights (information) and duties (cooperation) of works councils

- Veto rights of works councils in particular areas (e.g., recruitment and dismissal, wage system, work organization, training, technology, working time, etc.)

The three elements are combined in a weighted, additive index.

In addition, based on the argument that the performance effects of firm-level worker representation is conditional on the ability of the actors to develop mutual trust, Kittel (2000a, pp. 220-21) creates a second, dichotomous variable measuring the legitimacy of firmlevel collective agreements. The criterion for legitimacy is the existence of an explicit legal entitlement for firm-level negotiators to conclude collective agreements.

\section{Recommendations for Data Collection}

In the area of firm-level representation, little cross-country comparative work has been undertaken yet. This is due partly to the immense increase of complexity of the analysis; within national systems of industrial relations, firm-level agreements and regulation vary widely, even in highly institutionalized coordination systems such as the German, Austrian, or Swedish. Hence the study of firm-level behavior comes close to cross-national survey research, with all the costs and conceptual problems this involves. As a result, comparative studies tend to restrict their focus to the institutional framework conditions, highlighting particular incentives to specific behavior without being able to measure behavior directly because of lack of crosscountry firm-level surveys. Nonetheless, research investments in this area might close the gap between cross-country institutional analysis and within-country survey research. 


\section{Methods of Data Collection}

The standard method of data collection has been - and still is - an expert creating scores based on available quantitative and qualitative data taken from the secondary literature and primary data collected from associations. This approach was dominant in the Golden, Lange, and Wallerstein (1997) collection of data. During the 1990s a large literature on industrial relations in OECD countries has emerged and also studies on CEE countries and a selection of NICs have expanded, although from a very low level. Similarly, in many countries annual reports of trade unions - though only rarely of employers associations - document basic figures. For EU member countries, the information base has been massively increased by the European Industrial Relations Review (EIRR) and the European Industrial Relations Observatory Online (EIROnline)), while the European Employment and Industrial Relations Glossaries ((EMIRE) provide systematic background information. Both are edited by the European Foundation for the Improvement of living and working conditions (http://www.eiro.eurofound.ie). As far as labor law is concerned, the International encyclopedia for labor law and industrial relations (Blanpain 1977ff) is a regularly updated source for most countries in the world. We call this approach the "centralized" method because it attempts to concentrate most coding decisions in the organization that coordinates the project.

A second approach, which was the dominant strategy in Traxler, Blaschke and Kittel (2001), is based on a detailed standardized questionnaire filled out by country experts. The questionnaire was validated by comparing the answers to the existing literature. Ambivalent issues were discussed with the specialists in order to maximize comparability of data. We call this approach "organized decentralization" (in analogy to Traxler 1995) - or, for the sake of brevity, simply "decentralized" - because it delegates as many coding decisions to the country experts as possible while having the project coordinator monitor the individual decisions. We will compare the advantages and disadvantages of the two approaches by referring to the standard criteria of measurement quality: objectivity, reliability, and validity. ${ }^{10}$

\section{Objectivity}

In the literature on objectivity in data gathering methods, two subcriteria are discussed: implementation objectivity and evaluation objectivity (Diekmann 1995, pp. 216-217). Sometimes these issues are discussed under the heading of inter-coder reliability.

Implementation objectivity refers to the interviewer-respondent interaction: Do different interviewers obtain the same answer from the same respondent? In the current context, this criterion relates to the person or organization charged with data collection. For example, a researcher who is well known in the national setting to be sympathetic towards trade unions will find it harder to get access to data on employers associations. A different problem may occur if data collection is centralized in the ILO: since it is practically impossible to check data for all countries, data quality is difficult to assess. This issue is particularly salient for quantitative indicators like membership density, number of associations, financial aspects, etc.

In addition, if the data on a country are collected by a single person, personnel continuity in the organization charged with data collection is an important condition for ensuring temporal stability of data quality. This is probably easier to control the more data collection is centralized, but also more consequential if such changes in personnel occur.

\footnotetext{
${ }^{10}$ The GLW data set has been published at http://www.shelley.polisci.ucla.edu/data. Selected variables from the TBK data set are available for eight subperiods of the period 1970-1998 in Traxler, Blaschke and Kittel (2001).
} 
Evaluation objectivity refers to the extent to which two different observers evaluate an event equally. This criterion is relevant for "weak" data which involve an assessment of particular events, like bargaining rounds, strikes, state intervention in bargaining, associational strategy, etc. But textual sources also need to be interpreted and different researchers will stress different aspects more heavily, thereby suggesting different interpretations of the event which may result in different coding decisions. For this criterion, there is a clear trade-off between a centralized and a decentralized approach to data collection. The more decentralized data collection is, the closer the coding personnel is to the events and the more contextual information is available. However, the closer is the involvement of the coding personnel in the event, the higher is the potential bias induced by subjective evaluation. Of course, by charging more than one person with the coding of each country, this bias can be considerably reduced

Problems of objectivity may also be present if coding relies on secondary sources. But since secondary analysis relies on already-collected data, this issue cannot even be addressed as a problem and hence appropriateness of coding can only be assessed via ex post validity tests. Among these, the assessment of the similarity of indicators referring to the same concept and the difference between indicators referring to different concepts is perhaps the sole possibility to gain insight into the validity of a particular indicator. However, this approach relies heavily on the definition of particular concepts, which is in many instances still strongly disputed, ${ }^{11}$ and assumes that it is possible to devise, and collect data for, different indicators of such concepts.

\section{Reliability}

While objectivity refers to external factors influencing the coding decisions by the personnel charged with coding, reliability concerns the coding decision itself. Since the coding personnel updates its interpretation of past events any time new events occur and new information becomes available, past coding decisions might be revised. Among the standard approaches to reliability assessment — parallel test, test-retest, and split-half method — the most promising approach is the test-retest method because the other two involve synchronous data gathering. In the current context this method would imply that the coding personnel are allowed to update the information they provide on past events. A possible approach might be to ask to re-evaluate past assessments of events at regular intervals. However, this approach is likely to be hampered by potentially strong incentives not to change past codings. This may be due to either unwillingness to reassess former coding decisions or to attempts to maintain consistency of interpretation.

A possibility to apply the idea of a parallel test to the current context would be to let two people code events simultaneously but independently and discuss differences in assessment. This approach might have additional positive externalities if the two coders have a different affiliation - one closer to the trade unions and the other closer to the employers associations - in terms of data access and informal background information.

Reliability cast in the terms of the test-retest approach increases with centralization. Note, however, that maximizing reliability in these terms may not be the relevant objective; since information may be revealed only some time after an event, early assessments are bound to be based on incomplete information and a later change of assessment may not be due to erroneous coding but to lack of detailed information at the earlier point in time. Cast in terms of parallel tests, reliability increases with decentralization within a country because more information is used for evaluating some event.

\footnotetext{
${ }^{11}$ For example, the distinctions between core concepts like corporatist concertation and centralized wage bargaining or between corporatism and consensus democracy are far from being settled.
} 


\section{Validity}

Validity refers to the extent that theoretical concepts are captured by the indicators. In the literature, distinctions are made between content validity, construct validity, and criterionrelated validity (divided into concurrent validity and predictive validity). Since the last refers to an ex-post assessment of validity, we restrict our discussion to the first two. To a large extent, content validity - the extent to which an indicator represents the operational definition of the concept - has to be ascertained in the process of operationalization. However, several issues are relevant for data collection. For the centralized approach, the basic problem is to judge the validity of the information collected from secondary sources. Such data often have not been collected for the sake of research but for other ends (Jacob 1985). Hence, many readily available quantitative indicators are biased by construction and data which allow for corrections are difficult or impossible to obtain (Ebbinghaus and Visser 2000; Visser 1989). For example, the meticulous data collection on union density in OECD countries undertaken by Ebbinghaus and Visser (2000) still contains lacunas in more disaggregated (e.g. sectoral) density ratios. In addition, categorizations used by different organizations collecting statistical material often refer to different units. This makes it either very costly or practically impossible to match data from different sources. ${ }^{12} \mathrm{~A}$ further caveat is the unequal distribution of information, both across and within countries. Across countries, data on OECD member states are systematically more elaborate and reliable than data on other countries. But between OECD countries data availability differs markedly. To the extent that data needed for building measures on the structure of collective bargaining and organizational characteristics depend on information about, e.g., employment levels or employment distribution across sectors, data availability and quality differ considerably across countries. In addition, breaks in the time series due to redefinition of a particular concept cause fluctuations not related to any real-world developments. Within countries, some sectors (in particular the metal industry) are wellresearched while others (in particular in the private service sector) are notoriously underresearched. Also, it is much more difficult - in many instances practically impossible - to obtain data on employers associations than on trade unions. While large, unionized firms and their associations are usually willing to provide information to researchers, sectors dominated by small and medium-sized firms are much less accessible.

A similar problem occurs in textual data. Country studies are undertaken for the purpose of answering a particular research question, and the description therefore is focused on that question. Hence information provided in the text may suffice for the aims of the author but may lack the encompassingness needed for a comparative project. In addition, authors of case studies do not necessarily use the same definition of concepts as the project. This is a core problem for computer-coded textual analysis. Because concepts are used in slightly different ways in different countries and their meaning evolves over time, coding decisions made in advance are critical. Country glossaries as prepared by the EMIRE project of the European Foundation for the Improvement of Living and Working Conditions may be very helpful. But since such glossaries are only available for a handful of European countries, this does not aid in the analysis of other nations. Moreover, a possibly salient caveat with regard to this approach refers to the aims of the project. The main area of application of computer-coded textual analysis is the detection of subtexts, hidden agendas, background paradigms, and other elements "behind the lines." In the current context, where the aim is to extract "objective" information from the text, the advantages of computer coding must be evaluated against the costs. However, an information database similar to EIROnline or EIRR for countries not covered by these collections is certainly an enormous help for systematic comparative studies. But this again leads to country experts who have to select the information to be fed into such a system.

\footnotetext{
${ }^{12}$ For example, it proved to be excessively difficult to match wage data published by the Austrian employers association with data on sectoral union density obtained from union sources because both organizations collect their data for their own organizational units.
} 
In the decentralized approach, the country experts face the same issues of data definition, though their proximity to the research object may alleviate the problem somewhat. In this situation, the problem of content validity appears in the shape of communication deficiencies between the coordinator and the country coder. Since most concepts need operational definitions, coding decisions may be ambivalent. The ambivalence increases with the level of abstraction of the concepts used. Hence the more detailed and the narrower an item is framed, the less ambiguous is the response.

Construct validity enters comparative research via the notion of functional equivalence (van Deth 1998, p. 8). Since the same term or concept can have different meanings in different contexts, using the same indicators in each context may lead to erroneous inferences. The researcher has two options to deal with this problem: to increase the level of abstraction or to rely on inference. Increasing the level of abstraction may be a sensible option for inferential analysis but not necessarily for data collection. While it may have merits for comparative population survey research, we do not see any advantages in describing an industrial relations system only in abstract terms because this would restrict the generality of usage of the indicators. If only measures of general concepts are available, it becomes difficult to match them in different ways for different research questions.

Hence identity of concepts should be replaced by the equivalence of concepts, meaning that they "should be related to other concepts in other settings in more or less the same way" (van Deth 1998, p 6). This implies that equivalence of concepts across countries cannot be established ex ante. Since it is a relational notion, it is a result of inferences, not of data collection (Przeworski and Teune 1970; van Deth 1998, p. 8).

Analytically, one can distinguish two main inferential strategies for establishing equivalence across countries, each with two perspectives: (1) use a common set of indicators and analyze (a) internal consistency and (b) external consistency; (2) use different indicators and analyze (a) internal consistency and (b) external consistency. Both strategies move from an "absolute" approach to the operationalization of concepts to a "relational" approach. Because concepts have different meanings, frames and traditions across countries, they can only be compared in their relation to other concepts. Hence such an approach suggests to establish equivalence by analyzing concepts and their context in toto. By using a common set of indicators for all countries, the researcher attempts to remain as close to the literal operationalization as possible and explores the differences in the empirical association between the indicators across countries. In contrast, by using different indicators, the researcher first establishes a core set of identical items which are employed as an anchor for subsequently added country-specific items taking into account particular idiosyncracies of a country. In both contexts, internal consistency refers to the extent to which the items are structured identically across countries, and external consistency refers to the extent that items are related identically to an item not belonging to the initial set of items (van Deth 1998: 9).

Note, however, that these considerations refer to an ex-post comparison of statistical associations within and across countries in cross-country survey research. This is an important restriction because many industrial relations characteristics are system variables. This means that they are measured at the level of the whole country and are not aggregated from individuallevel data. Hence, although the practical relevance of the proposed solution strategies remains limited in the present case, the problem of equivalence is highly salient. Nevertheless, they may be regarded as a guide for further reflection on the solution of the yet-unresolved problem of the equivalence of system-level variables. Which strategy to follow depends on the research question and cannot be answered in toto. The implication for data collection is that the more differentiated information is available, the easier it is to construct equivalent indicators. In this respect, the decentralized approach is clearly advantaged as compared to the centralized approach because it makes it possible to address issues of equivalence explicitly by design and highlight the problem in the communication process between the coordinating agency and the country experts. 


\section{Recommendations for Data Collection}

We have compared the relative merits and potentially problematic areas of commonly used quality criteria of two approaches to data collection. Table 1 summarizes our assessment of the two methods and clearly suggests that expert surveys are preferable for the creation of a useful database on social dialogue.

Table 1. Quality Criteria and Two Approaches to Data Collection

\begin{tabular}{|c|c|c|c|}
\hline & & $\begin{array}{l}\text { Decentralized: Survey of } \\
\text { Country Experts }\end{array}$ & Centralized: Secondary Analysis \\
\hline \multirow[t]{2}{*}{ Objectivity } & Implementation & Problematic but tractable & Intra \\
\hline & Evaluation & Problematic but tractable & Intra \\
\hline \multirow[t]{2}{*}{ Reliability } & Parallel test & $\begin{array}{l}\text { Simple but costly } \\
\text { ( } 2 \text { coders) }\end{array}$ & Dependent on data availability \\
\hline & Test-retest & Regular updating & Dependent on data availability \\
\hline \multirow[t]{2}{*}{ Validity } & Content validity & $\begin{array}{l}\text { Dependent on design of } \\
\text { questionnaire }\end{array}$ & $\begin{array}{l}\text { Dependent on data availability and } \\
\text { conceptualization in previous research }\end{array}$ \\
\hline & $\begin{array}{l}\text { Construct } \\
\text { validity }\end{array}$ & $\begin{array}{l}\text { Dependent on design of } \\
\text { questionnaire }\end{array}$ & $\begin{array}{l}\text { Dependent on data availability and } \\
\text { conceptualization in previous research }\end{array}$ \\
\hline
\end{tabular}

However, the problems associated with expert surveys should not be underestimated. In order to maximize objectivity, validity, and reliability, the data collection endeavor needs strict central guidance and monitoring. Hence the role of the coordinating agency is important and it should possess enough evaluative capacity to judge at least the face validity of the coded results. The quality of the database could be massively improved, in particular for those issues that need evaluative judgment, if two independent coders work on the same country. The disadvantage is that this doubles the cost of data collection. If costs seem excessive, a possible option for optimizing the output/cost ratio would be to build in a two-step peer review system, in which the coding for a particular country is reviewed by one or two coders for other countries. Despite the disadvantage that the review coders must rely on secondary information only, this procedure might highlight possible ambivalences in coding.

\section{Summary and Conclusion}

On both theoretical and empirical grounds, institutions related to social dialogue appear to be relatively important as determinants of key socioeconomic performance outcomes. Regularized collection of data on these institutions - ideally in both affluent and developing nations - would be of enormous benefit to researchers, and ultimately to policy makers. We have reviewed existing indicators in four areas: (1) associational structure, (2) wage-setting arrangements, (3) participation in public policy, and (4) firm-level representation. We have also provided specific suggestions for data collection in each of these areas, at the ends of sections 2 through 5 (subsections titled "Recommendations for Data Collection"). Regarding general methodological issues of data collection, we offer two main recommendations: First, we believe the most useful strategy for data collection would rely on a detailed standardized questionnaire filled out by country experts, with their responses validated by comparing them with the existing literature and resolving discrepancies via discussion with the experts. Second, we advise that indicators for which data are collected be as narrow and detailed as possible. The less aggregated each single measure is, the less ambiguous it is. Hence the higher is the validity of cross-country comparisons and the better traceable are developments over time. Such simple indicators can then be used for building more aggregated indicators. 


\title{
Appendix: Existing Social Dialogue Indicators
}

\author{
Associational Structure
}

Union Density

Ebbinghaus-Visser union density. Nonretired union members as a percentage of the labor force. 16 OECD countries; 1945 through the mid-1990s. Source: Ebbinghaus and Visser (2000).

\section{Union Concentration}

Schmitter union concentration. Rank ordering (we reversed the scores so that higher scores indicate greater centralization). 15 OECD countries; no years specified (time-invariant). Source: Schmitter (1981, p. 294, "associational monopoly").

Cameron union concentration. Index ranging from 0 to 1.18 OECD countries; 1965-80 (time invariant). Source: Cameron (1984, p. 165, "organizational unity of labor").

Golden-Lange-Wallerstein (GLW) interassociational union concentration I. Herfindahl index of concentration across the eight largest union confederations. 16 OECD countries; 1950-92. Source: Golden, Lange and Wallerstein (1997, variable = HERF).

Golden-Lange-Wallerstein (GLW) interassociational union concentration II. Share of the total unionized workforce organized into confederations for which GLW have membership data. 16 OECD countries; 1950-92. Source: Golden, Lange and Wallerstein (1997, variable = CONSHRE).

Golden-Lange-Wallerstein (GLW) intra-associational union concentration I. Approximate Herfindahl index of union concentration for affiliates of the largest union confederation, using the membership of the three largest affiliates and the total number of affiliates. 16 OECD countries; 1950-92 (5-year intervals). Source: Golden, Lange and Wallerstein (1997, variable = APPHRF1).

Golden-Lange-Wallerstein $(G L W)$ intra-associational union concentration II. Approximate Herfindahl index of union concentration for affiliates of the four largest union confederations (weighted by confederation size), using the membership of the three largest affiliates and the total number of affiliates. 16 OECD countries; 1950-92 (5-year intervals). Source: Golden, Lange and Wallerstein $(1997$, variable $=$ APPHRFWT $)$.

Traxler-Blaschke-Kittel (TBK) interassociational union concentration I. Number of national, interindustry (i.e., covering at least two one-digit ISIC sectors) union peak organizations. 20 OECD countries; 1970-98. Source: Traxler, Blaschke and Kittel (2001, pp. 314, 41, variable = USYS).

Traxler-Blaschke-Kittel (TBK) interassociational union concentration II. Share of the largest national, interindustry union peak in total union membership. 20 OECD countries; 1970-98. Source: Traxler, Blaschke and Kittel (2001, pp. 314, 41, variable = USYSL).

Traxler-Blaschke-Kittel (TBK) interassociational union concentration III. Membership share of unions not affiliated to any national, interindustry union peak. 20 OECD countries; 1970-98. Source: Traxler, Blaschke and Kittel (2001, pp. 313, 41, variable = UNAF).

Traxler-Blaschke-Kittel (TBK) intra-associational union concentration I. Number of affiliates of the largest union peak. 20 OECD countries; 1970-98. Source: Traxler, Blaschke and Kittel (2001, pp. 312, 46 , variable $=\mathrm{UAF}$ ).

Traxler-Blaschke-Kittel (TBK) intra-associational union concentration II. Share of the three strongest affiliates in the largest union peak's total membership. 20 OECD countries; 1970-98. Source: Traxler, Blaschke and Kittel (2001, pp. 312, 46, variable = UAS). 


\section{Employer Concentration}

Traxler-Blaschke-Kittel (TBK) interassociational employer concentration. Number of national, interindustry (i.e., covering at least two one-digit ISIC sectors) employer peak organizations. 20 OECD countries; 1970-98. Source: Traxler, Blaschke, and Kittel (2001, pp. 310, 49, variable = ESYS).

Traxler-Blaschke-Kittel (TBK) intra-associational employer concentration. Number of direct affiliates of the largest employer peak. 20 OECD countries; 1970-98. Source: Traxler, Blaschke and Kittel (2001, pp. 309,55 , variable $=\mathrm{EAF}$.

\section{Union Centralization}

Schmitter union centralization. Rank ordering (I reversed the scores so that higher scores indicate greater centralization). 15 OECD countries; no years specified (time invariant). Source: Schmitter (1981, p. 294, "organizational centralization").

Cameron union centralization. Index ranging from 0 to 1.18 OECD countries; 1965-80 (time invariant). Source: Cameron (1984, p. 165, "confederation power in collective bargaining").

Kenworthy union centralization. Index ranging from 0 to 4 . Calculated as the number of the following powers/capacities that the main union confederation has: power of appointment of affiliates, veto over wage agreements by affiliates, veto over strikes, confederation has its own strike funds. 16 OECD countries; 1950-92: Ireland, New Zealand. Source: Kenworthy (2000). Constructed from data in Golden, Lange and Wallerstein (1997, variables = CON11, CON12, CON13, CON14).

Traxler-Blaschke-Kittel (TBK) union centralization I. Associational centralization: largest union peak organization. The largest union peak's formal power vis-à-vis its direct affiliates is contingent on its right to (1) conclude collective agreements on behalf of its affiliates; (2) receive a share in dues collected by affiliates; (3) have its own strike fund; (4) veto collective agreements signed by affiliates; (5) veto strikes by affiliates; (6) participate in demand formulation and/or bargaining of affiliates; and (7) on the peak's obligation to submit the ratification of collective agreements to a membership ballot. Since the peak's formal powers increase with the number of rights and decrease with obligations, in constructing the aggregate index of the peak's formal power the authors code yes $=1$ and no $=0$ for items 1-6 and yes $=0$ and no $=1$ for item 7. 20 OECD countries; 1970-98. Source: Traxler, Blaschke and Kittel (2001, pp. 310, 49, variable = UCENP).

Traxler-Blaschke-Kittel (TBK) union centralization II. Associational centralization: direct affiliates of the largest union peak. The affiliates' formal power is contingent on their right to (1) conclude collective agreements on behalf of their members, (2) have their own strike fund, (3) veto collective agreements signed by any lower-level bargaining unit, (4) veto strikes by an lower-level unit, (5) participate in demand formulation and/or bargaining of lower-level units, and (6) on the affiliates' obligation to submit the ratification of collective agreements to a membership ballot. Constructed in a way analogous to their UCENP measure (see above). If the formal power varies across the affiliates, the measure refers to the most common pattern or the most influential affiliate. 20 OECD countries; 1970-98. Source: Traxler, Blaschke, and Kittel (2001, pp. 310, 49, variable = UCENA).

Traxler-Blaschke-Kittel (TBK) union centralization III. Associational centralization: control of union organizations over member firms under the umbrella of the largest peak. Formal control over member firms decreases when the latter are entitled to (1) organize strikes, (2) control their own strike fund, and (3) conclude collective agreements; while the control increases when (4) they are formally guaranteed representation on that union body conducting collective bargaining at a higher level. Aggregate index of items 1-4. For items 1-3, yes $=-1$, no $=0$; for item 4 , yes $=1$, no $=0$. each coded yes $=-1$, no $=0$. Reference is to the most common pattern or the most influential affiliate in the case of intra-confederal variation. 20 OECD countries; 1970-98. Source: Traxler, Blaschke and Kittel (2001, pp. 310, 49, variable $=\mathrm{UCENW})$.

Traxler-Blaschke-Kittel (TBK) union centralization IV. Unionpeak control over lower hierarchical levels: aggregate index derived from scores for their UCENP, UCENA (items 3-6), and UCENW measures (see above); standardized to the $0-1$ interval. Union centralization increases with score. 20 OECD countries; 1970-98. Source: Traxler, Blaschke and Kittel (2001, pp. 310, 49, variable = UCEN). 


\section{Employer Centralization}

Kenworthy employer centralization. Index with 3 categories: $1=$ no peak employer confederation. $2=$ peak employer confederation exists but has none of the powers/resources listed under 3 below. $3=$ peak employer confederation exists and has one or more of the following: power of appointment of affiliates, veto over wage agreements, veto over lockouts, confederation has its own conflict funds. The scoring for this index differs from that of Kenworthy union centralization for two reasons. First, while all of the countries have a peak union confederation, some do not have a counterpart business confederation. Second, there is little variation among countries that do have a peak business confederation in the number of powers/capacities held by the confederation. 16 OECD countries; 1950-92. Source: Kenworthy (2000). Constructed from data in Golden, Lange and Wallerstein (1997, variables = EMCONV1, EMCONV2, EMCONV3, EMCONV4, EMCONV5).

Traxler-Blaschke-Kittel (TBK) employer centralization I. Associational centralization: largest employer peak organization. The largest employer peak's formal power vis-à-vis its direct affiliates is contingent on its right to (1) conclude collective agreements on behalf of its affiliates; (2) receive a share in dues collected by affiliates; (3) have its own fund for industrial action; (4) veto collective agreements signed by affiliates; (5) veto lockouts by affiliates; (6) participate in demand formulation and/or bargaining of affiliates; and (7) on the peak's obligation to submit the ratification of collective agreements to a membership ballot. Since the peak's formal powers increase with the number of rights and decrease with obligations, in constructing the aggregate index of the peak's formal power the authors code yes = 1 and no $=0$ for items $1-6$, and yes $=0$ and no $=1$ for item 7 . Scored 0 if there is no employer peak organization. 20 OECD countries; 1970-98. Source: Traxler, Blaschke and Kittel (2001, pp. 310, 49, variable $=\mathrm{ECENP})$.

Traxler-Blaschke-Kittel (TBK) employer centralization II. Associational centralization: direct affiliates of the largest employer peak. The affiliates' formal power is contingent on their right to (1) conclude collective agreements on behalf of their members, (2) have their own fund for industrial action, (3) veto collective agreements signed by any lower-level bargaining unit, (4) veto lockouts by an lower-level unit, (5) participate in demand formulation and/or bargaining of lower-level units, and (6) on the affiliates' obligation to submit the ratification of collective agreements to a membership ballot. Constructed in a way analogous to their ECENP measure (see above). Scored 0 if there is no employer peak organization. If the formal power varies across the affiliates, the measure refers to the most common pattern or the most influential affiliate. 20 OECD countries; 1970-98. Source: Traxler, Blaschke, and Kittel (2001, pp. 310, 49, variable = ECENA).

Traxler-Blaschke-Kittel (TBK) employer centralization III. Associational centralization: control of employer organizations over member firms under the umbrella of the largest peak. Formal control over member firms decreases when the latter are entitled to (1) obtain the status of a 'non-conforming' member generally not subject to collective agreements signed by the association; (2) conduct separate negotiations on their own when a collective agreement by the association is not in line with the firm's interest; (3) autonomously organize industrial action; (4) pay their employees more than the amount fixed by the collective agreement signed by the association. Aggregate index of items 1-4 each coded yes $=-1$, no $=0$. Scored -4 if there is no employer peak organization. Reference is to the most common pattern or the most influential affiliate in the case of intra-confederal variation. 20 OECD countries; 1970-98. Source: Traxler, Blaschke and Kittel (2001, pp. 310, 49, variable = ECENF).

Traxler-Blaschke-Kittel (TBK) employer centralization IV. Employer peak control over lower hierarchical levels: aggregate index derived from scores for their ECENP, ECENA (items 3-6), and ECENF measures (see above); standardized to the 0-1 interval. Employer centralization increases with score. 20 OECD countries; 1970-98. Source: Traxler, Blaschke and Kittel (2001, pp. 310, 49, variable $=\mathrm{ECEN})$. 


\title{
Wage-Setting Arrangements
}

\author{
Wage Centralization
}

Cameron wage centralization. Index ranging from 0 to 1 . "Nations were assigned values between 0 and 1.0 on a seven-point scale that, in ascending order, moves from restricted collective bargaining (as in Spain in the Franco era), to highly decentralized company-level bargaining with company unions, to decentralized bargaining with national unions, to partially centralized bargaining with company and regional or multi-employer negotiations, to partial industry-wide bargaining, to full industry-wide bargaining, and finally to industry-wide bargaining with economy-wide formally negotiated agreements." 18 OECD countries; 1965-80 (time invariant). Source: Cameron (1984, pp. 164-65, variable $=$ scope of collective bargaining).

Calmfors-Driffill wage centralization. Rank ordering (we reversed the scores so that higher scores indicate greater centralization) based on the degree of coordination within central organizations of labor and business and the degree of cooperation between such organizations. 17 OECD countries; no years specified (time invariant). Source: Calmfors and Driffill (1988, pp. 18, 52-53).

OECD wage centralization. Index ranging from 1 to 3. 19 OECD countries; 1980, 1990, and 1994. Source: OECD (1997, p. 71).

Golden-Lange-Wallerstein $(G L W)$ involvement by union and employer confederation(s) in wage setting. Index with 11 categories: 1 = Confederation(s) uninvolved in wage setting in any of the subsequent ways. 2 = Confederation(s) participates in talks or in formulation of demands for some affiliates. $3=$ Confederation(s) participates in talks or in formulation of demands for all affiliates. $4=$ Confederation(s) negotiates non-wage benefits. $5=$ Confederation(s) negotiates a part of the wage agreement, such as the cost-of-living adjustment. $6=$ Confederation(s) represents affiliates in mediation with centralized ratification. $7=$ Confederation(s) represents affiliates in arbitration. $8=$ Confederation(s) bargains for affiliates in industry-level negotiations. $9=$ Confederation(s) negotiates national wage agreement without peace obligation. $10=$ Confederation(s) negotiates national wage agreement with peace obligation. $11=$ Confederation(s) negotiates national wage agreement with limits on supplementary bargaining. 16 OECD countries; 1950-92. Source: Golden, Lange and Wallerstein (1997, variable $=$ CONINV); for discussion see Wallerstein (1999).

Golden-Lange-Wallerstein (GLW) government involvement in wage setting. Index with 15 categories: $1=$ Government uninvolved in wage setting. 2 = Government establishes minimum wage(s). $3=$ Government extends collective agreements. $4=$ Government provides economic forecasts to bargaining partners. $5=$ Government recommends wage guidelines or norms. $6=$ Government and union negotiate wage guidelines. $7=$ Government imposes wage controls in selected industries. $8=$ Government imposes cost-of-living adjustment. $9=$ Formal tripartite agreement for national wage schedule without sanctions. $10=$ Formal tripartite agreement for national wage schedule with sanctions. $11=$ Government arbitrator imposes wage schedules without sanctions on unions. $12=$ Government arbitrator imposes national wage schedule with sanctions. $13=$ Government imposes national wage schedule with sanctions. $14=$ Formal tripartite agreement for national wage schedule with supplementary local bargaining prohibited. $15=$ Government imposes wage freeze and prohibits supplementary local bargaining. 16 OECD countries; 1950-92. Source: Golden, Lange and Wallerstein $(1997$, variable $=$ GOVIN $)$; for discussion see Wallerstein (1999).

Golden-Lange-Wallerstein $(G L W)$ overall wage centralization. Index with 4 categories: $1=$ Plant-level wage setting. 2 = Industry-level wage setting. 3 = Centralized wage setting without sanctions. $4=$ Centralized wage setting with sanctions. 16 OECD countries; 1950-92. Source: Golden, Lange, and Wallerstein (1997, variable = BARGLEV); for discussion see Wallerstein (1999). 
Iversen wage centralization. Index ranging from 0 to 1 (actual range of scores is from .071 to .654). Calculated as $\sum\left(w_{j} p_{i j}^{2}\right)^{1 / 2}$, where $w_{j}$ is the weight accorded to each bargaining level $j\left(\sum w_{j}=1\right)$ and $p_{i j}$ is the share of workers covered by union (or federation) $i$ at level $j$. (The square root is used simply to heighten somewhat the difference in scores between decentralized cases.) The index combines a measure of the prevalent level of bargaining $\left(w_{j}\right)$ with a measure of union concentration $\left(p_{i j}\right)$. There are 7 weight scores for bargaining level (each with a weight for centralized, intermediate, and decentralized, respectively); these are listed in the text. 16 OECD countries; 1973-93. Source: Iversen (1999, pp. 48-57, 83-85; data at http://www.people.fas.harvard.edu/ iversen).

Traxler-Blaschke-Kittel (TBK) wage centralization. Index of centralization of bargaining level, with ranking based on the most important level and special scores in case of equally important levels. There are 12 categories; these are listed in the text. 20 OECD countries; 1970-98. Source: Traxler, Blaschke, and Kittel (2001, pp. 114, 307, variable = BCEN).

\section{Wage Coordination}

Crouch wage coordination. Dichotomous measure: $0=$ Uncoordinated ("liberal"). 1 = Coordinated ("neocorporatist"). 18 OECD countries; no years specified (time invariant). Source: Crouch (1985, p. 117).

Soskice wage coordination. Index ranging from 0 to 5. United States and United Kingdom (0): zero employer and union coordination. France (1.5): tacit government coordination via public services and large nationalized industry sector. Italy (2): informal employer coordination via big employers, especially Fiat, IRI, and some regional employer associations; some help from union confederations, CGIL and CISL. Netherlands (3): strong employer organizations and informal coordination between giant companies; occasional differences between giants and industry organizations; medium union coordination. Germany (3.5): strong employer organizations, with considerable coordination across industries; medium-strong union coordination. Sweden (4): powerful centralized employer organization; generally strong coordination across industries, with some divergence of interests; centralized union confederations with some internal conflicts. Norway (4): as Sweden, with government playing an additional coordinating role. Switzerland (4): very powerful employer organizations, playing tacit coordinating role; unions weak and pliant. Austria (5): very powerful union, with centralized coordinating role; medium-strong employer organizations. Japan (5): very powerful tacit employer coordination across large companies, in more or less centralized way, with backing from industry employer organizations; weak and pliant unions. 11 OECD countries; mid-to-late 1980s (time invariant). Source: Soskice (1990, p. 55).

Layard-Nickell-Jackman wage coordination. Index ranging from 2 to 6. Sum of index for coordination by unions and index for coordination by employers, each of which ranges from 1 to 3. 20 OECD countries; 1983-88 and 1989-94. Source: Layard and Nickell (1994, p. 277); Nickell (1997, pp. 26, 63). Both draw on Layard, Nickell and Jackman (1991, Annex 1.4).

OECD wage coordination. Index ranging from 1 to 3. 19 OECD countries; 1980, 1990, and 1994. Source: OECD (1997, p. 71).

Hall-Franzese wage coordination. Index with 5 categories: $0, .25, .50, .75,1.0 .21$ OECD countries; 1955-90 (time invariant). Source: Hall and Franzese (1998; data at http://wwwpersonal.umich.edu/ franzese, variable = HCWB); for discussion see Hall and Franzese (1998, p. 516).

Traxler-Blaschke-Kittel (TBK) wage coordination mode. Categorical classification of the "mode of macro-coordination of wages," as listed in the text. 20 OECD countries: 1970-98. Source: Traxler, Blaschke and Kittel (2001, pp. 150, 308, variable = BMO).

Kenworthy wage coordination. This variable represents a set of predictions about the degree of coordination likely to be generated by wage bargaining arrangements in various countries. Index with 5 categories; scores are listed in the text. 18 OECD countries; 1960-2000. Source: Kenworthy (2001a). 


\section{Participation in Public Policy}

Lehmbruch corporatist concertation. Classification based on the nature of trade union participation in public policy formation. pluralism (United States, Canada, Australia, New Zealand): predominance of pressure groups, low degree of effective participation by unions; weak corporatism (United Kingdom, Italy): institutionalized participation of organized labor in the formation and implementation of policies in certain limited sectors of policy or only in specific stages; medium corporatism (Ireland, Belgium, Germany, Denmark, Finland, Switzerland): sectoral union participation with broader scope of collective bargaining plus attempts at concerted incomes policy; strong corporatism (Austria, Sweden, Norway, Netherlands): effective participation of labor unions (and organized business) in policy formation and implementation across those interdependent policy areas that are of central importance for the management of the economy; concertation without labor (France, Japan): special cases of cooperation between the government and 'big business'. 16 OECD countries; no years specified (time invariant). Source: Lehmbruch (1984).

Lijphart-Crepaz corporatism. Average of 12 expert scores on policy formation and interest intermediation (validity problems!). 18 OECD countries; approximately 1950-80 (time invariant). Source: Lijphart and Crepaz (1991).

Hicks and Kenworthy cooperation between government and interest groups. 3-point scale: (0) relatively cooperative interaction between cohesive government agencies and coordinated business and labor organizations; (0.5) moderate cooperation; and (1) relatively combative, conflictual relationship[s] between fragmented state agencies and interest group organizations. 18 OECD countries; 1960-89. Source: Hicks and Kenworthy (1998, pp. 1642-43).

Siaroff integrated economies. 3 dimension of the synthetic index of corporatism refer to policy formation. (a) The nature of conflict resolution focuses on the way in which the state and the labor market associations coordinate their policies: $5=$ bargained or networked; $4=$ bargained or networked with some state imposition of policies or some pluralism; $3=$ pluralist or liberal (hands-off state); $2=$ statist, with some inclusion of economic actors; or pluralist, with some state imposition of policies; $1=$ statist. (b) Generalized political exchange: $5=$ extensive, both at the sectoral and the national level; $4=$ extensive at either the sectoral or the national level; 3 = formerly extensive but now clearer weaker in various ways and various levels; $2=$ incipient or weak; $1=$ none. (c) The general nature of publicprivate interaction: $5=$ concordance (encompassing co-ordination); $4=$ strong corporatism; $3=$ moderate corporatism; 2 = weak corporatism; 1 = pluralism. 24 OECD countries; four periods from late 1960s to mid-1990s. Source: Siaroff (1999).

Boreham-Compston labor participation in public policy making. 10-point scale ranging from systems in which union confederations formally participate in policy formulation across three or more policy areas on a regular basis (highest scores) to systems in which some unions are involved in policy consultations but no input is sought from the major confederations. 11 OECD countries; 1973-86. Source: Boreham and Compston (1992).

Compston labor participation in public policy making. Drawing from Boreham and Compston (1992) and Compston (1994, 1995a, 1995b). 10-point scale, ranging from no participation (0) via narrow consultation (1-3), broad consultation (4-6) and narrow agreement (7-8) to broad agreement (9-10). 13 OECD countries; 1970-92. Source: Compston (1997).

Traxler-Blaschke-Kittel (TBK) associational participation in state regulation. Aggregate index based on dichotomous scores of the participation of trade unions in particular policy areas. 20 OECD countries; 1970-96. Source: Traxler, Blaschke, and Kittel (2001).

Tálos-Kittel associational participation. 8-point ranking based on accordation, concertation, and involvement, used for a comparison of 145 law-making processes in various policy areas in Austria, late 1960s to 2000. Each individual law-making process has been coded. Source: Tálos and Kittel (2001). 


\section{Firm-Level Representation}

Kittel institutionalized firm-level worker representation. 10-point scale derived from three elements: (1) legal foundation (law $=4$ points; collective agreement $=2$ points; firm-level agreement $=0$ points); (2) information right and cooperation duty of works councils (each 1 point); and (3) veto rights of works councils (for each of 8 areas 0.5 points). 20 OECD countries; 8 periods, 1970-96. Source: Kittel (2000a).

Kittel firm-level collective agreements. Dichotomous measure. 0 if firm-level agreements do not have a legal basis and 1 if firm-level agreements are based on a legal provision. 20 OECD countries; 8 periods, 1970-96. Source: Kittel (2000a). 


\section{References}

Blanpain, Roger. 1977ff. International Encyclopaedia for Labour Law and Industrial Relations, Vol. 1-13, (Deventer: Kluwer).

Boreham, Paul, and Hugh Compston. 1992. "Labour Movement Organization and Political Intervention: The Politics of Unemployment in the OECD Countries, 1974-1986" in European Journal of Political Research, vol. 22, pp. 143-170.

Bruno, Michael and Jeffrey Sachs. 1985. Economics of Worldwide Stagflation. (Cambridge: Cambridge University Press).

Calmfors, Lars and John Driffill. 1988. "Bargaining Structure, Corporatism, and Macroeconomic Performance." in Economic Policy, vol.6, pp. 14-61.

Cameron, David R. 1984. "Social Democracy, Corporatism, Labour Quiescence, and the Representation of Economic Interest in Advanced Capitalist Society." in Order and Conflict in Contemporary Capitalism, edited by John H. Goldthorpe, (Oxford: Clarendon Press), pp. 143-178.

Compston, Hugh. 1994. "Union Participation in Economic Policy-Making in Austria, Switzerland, The Netherlands, Belgium and Ireland, 1970-1992" in West European Politics, vol. 17, pp. 123-145.

Compston, Hugh. 1995a. "Union Participation in Economic Policy-Making in France, Italy, Germany, and Britain, 1970-1993" in West European Politics, vol. 18, pp. 314-339.

Compston, Hugh. 1995b. "Union Participation in Economic Policy-Making in Scandinavia, 1970-1993" in West European Politics, vol. 18, pp. 98-115.

Compston, Hugh. 1997. "Union Power, Policy Making, and Unemployment in Western Europe, 1972-1993" in Comparative Political Studies, vol. 30, pp. 732-751.

Cukierman, Alex and Francesco Lippi. 1999. "Central Bank Independence, Centralization of Wage Bargaining, Inflation, and Unemployment: Theory and Some Evidence" in European Economic Review, vol. 43, pp. 1395-1434.

Crouch, Colin. 1985. "Conditions for Trade Union Wage Restraint" in The Politics of Inflation and Economic Stagnation, edited by Leon N. Lindberg and Charles S. Maier (Washington, DC: Brookings Institution), pp. 105-139.

Diekmann, Andreas. 1995. Empirische Sozialforschung. Grundlagen, Methoden, Anwendungen. (Reinbek: Rowohlt).

Ebbinghaus, Bernhard and Jelle Visser. 2000. Trade Unions in Europe since 1945 (London: Macmillan).

Flanagan, Robert J. 1990. "Centralized and Decentralized Pay Determination in Nordic Countries", in Wage Formation and Macroeconomic Policy in the Nordic Countries, edited by Lars Calmfors. (Oxford: Oxford University Press).

Freeman, Richard B. and James L. Medoff. 1984. What Do Unions Do? (New York: Basic Books).

Garrett, Geoffrey. 1998. Partisan Politics in the Global Economy (New York: Cambridge University Press).

Garrett, Geoffrey and Christopher Way. 1999. "Public Sector Unions, Corporatism, and Macroeconomic Performance" in Comparative Political Studies, vol. 32, pp. 411-434.

Golden, Miriam. 1993. "The Dynamics of Trade Unionism and National Economic Performance" in American Political Science Review, vol. 87, pp. 439-54.

Golden, Miriam, Peter Lange, and Michael Wallerstein. 1997. "Union Centralization among Advanced Industrial Societies: An Empirical Study," version dated 11/2/98. Data set available at www.shelley.polisci.ucla.edu/data. 
Hall, Peter A. and Robert J. Franzese, Jr. 1998. "Mixed Signals: Central Bank Independence, Coordinated Wage Bargaining, and European Monetary Union" in International Organization, vol. 52, pp. 505-535.

Hayek, Friedrich A. 1960. The Constitution of Liberty (Chicago: University of Chicago Press).

Headey, Bruce W. 1970. "Trade Unions and National Wage Policies" in Journal of Politics, vol. 32, pp. 407-439.

Hibbs, Douglas A., Jr. and Håkan Locking. 1996. "Wage Compression, Wage Drift, and Wage Inflation in Sweden" in Labour Economics, vol. 3, pp.109-141.

Hicks, Alexander and Lane Kenworthy. 1998. "Cooperation and Political Economic Performance in Affluent Democratic Capitalism" in American Journal of Sociology,vol.103, pp. 1631-1672.

Hicks, Alexander and Duane Swank. 1992. "Politics, Institutions, and Welfare Spending in Industrialized Democracies, 1960-82" in American Political Science Review, vol. 86, pp. 658-674.

Hirsch, Barry T. 1992. "Firm Investment Behavior and Collective Bargaining Strategy", in Labor Market Institutions and the Future Role of Unions, edited by M. F. Bognanno and M. M. Kleiner (Oxford: Blackwell).

Iversen, Torben. 1999. Contested Economic Institutions: The Politics of Macroeconomics and Wage Bargaining in Advanced Democracies (Cambridge: Cambridge University Press).

Jacob, Herbert. 1985. Using Published Data. Errors and Remedies. Quantitative Applications in the Social Sciences 42 (London: Sage).

Keman, Hans and Paul Pennings. 1995. "Managing Political and Societal Conflict in Democracies: Do Consensus and Corporatism Matter?" in British Journal of Political Science, vol. 25, pp. 271-281.

Kenworthy, Lane. 1995. In Search of National Economic Success: Balancing Competition and Cooperation. (Thousand Oaks, CA: Sage).

1996. "Unions, Wages, and the Common Interest", in Comparative Political Studies, vol. 28, pp.491-524.

2000. "Quantitative Indicators of Corporatism" Discussion Paper 00-4. Max Planck Institute for the Study of Societies, Cologne, Germany.

_. 2001a. "Wage-Setting Coordination Scores", version dated June 17, 2001. Data set available at http://www.emory.edu/SOC/lkenworthy.

— 2001b. "Wage-Setting Measures: A Survey and Assessment", in World Politics, vol. 54, pp. 57-98.

—. 2002. "Corporatism and Unemployment in the 1980s and 1990s", in American Sociological Review, forthcoming.

Kittel, Bernhard. 2000a. "Gesamtwirtschaftliche Leistungseffekte betrieblicher Arbeitnehmervertretung im internationalen Vergleich" in Industrielle Beziehungen, vol. 7, pp. 211-229.

2. 2000b. "Trade Union Bargaining Horizons in Comparative Perspective: The Effects of Encompassing Organization, Unemployment, and the Monetary Regime on Wage Pushfulness", in European Journal of Industrial Relations, vol. 6, pp. 181-202.

Lange, Peter and Geoffrey Garrett. 1985. "The Politics of Growth: Strategic Interaction and Economic Performance in the Advanced Industrial Democracies, 1974-1980", in Journal of Politics, vol. 47, pp. 792-827.

Lange, Peter, Michael Wallerstein, and Miriam Golden 1995. "The End of Corporatism? Wage Setting in the Nordic and Germanic Countries", in The Workers of Nations, edited by Sanford Jacoby. (New York: Oxford University Press).

Layard, Richard and Stephen Nickell. 1994. "Unemployment in the OECD Countries" in Labour Market and Economic Performance, edited by Toshiaki Tachibanaki. (New York: St. Martin's Press), pp. 253-295. 
Layard, Richard, Stephen Nickell, and Richard Jackman. 1991 in Unemployment: Macroeconomic Performance and the Labor Market (Oxford: Oxford University Press).

Lehmbruch, Gerhard. 1984. "Concertation and the Structure of Corporatist Networks" in Order and Conflict in Contemporary Capitalism, edited by J. H. Goldthorpe (Oxford: Clarendon Press).

Lijphart, Arend and Marcus M.L. Crepaz. 1991. "Corporatism and Consensus Democracy in Eighteen Countries: Conceptual and Empirical Linkages" in British Journal of Political Science, vol. 21, pp. 235-246.

Mishel, Lawrence and Paula B. Voos, eds. 1992. Unions and Economic Competitivenss Armonk, NY: M. E. Sharpe).

Nardinelli, C., M.S. Wallace, and J.T. Warner. 1987. "Explaining Differences in State Growth: Catching Up versus Olson" in Public Choice vol. 52, pp. 201-213.

Nickell, Stephen. 1997. "Unemployment and Labor Market Rigidities: Europe versus North America" in Journal of Economic Perspectives, vol. 11, No. 3, pp. 55-74.

Nickell, Stephen and Richard Layard. 1999. "Labor Market Institutions and Economic Performance." in Handbook of Labor Economics, edited by Orley Ashenfelter and David Card. Amsterdam: Elsevier, vol. 3C, pp. 3029-84.

OECD (Organization for Economic Cooperation and Development). 1994. "Collective Bargaining: Levels and Coverage" in OECD Employment Outlook, (Paris: OECD), pp. 167-194

- 1997. "Economic Performance and the Structure of Collective Bargaining." in OECD Employment Outlook. (Paris: OECD), pp. 63-93

Olson, Mancur. 1982. The Rise and Decline of Nations. (New Haven, CT: Yale University Press).

Przeworski, Adam and Henry Teune. 1970. The Logic of Comparative Social Inquiry. (New York: Wiley).

Rogers, Joel and Wolfgang Streeck, eds. 1995. Works Councils: Consultation, Representation, and Cooperation in Industrial Relations (Chicago: University of Chicago Press).

Romanis, Anne. 1967. "Cost Inflation and Incomes Policy in Industrial Countries" in International Monetary Fund Staff Papers 14.

Scharpf, Fritz. 1991. Crisis and Choice in European Social Democracy. (New York: Cornell University Press).

Schmitter, Philippe C. 1974. "Still the Century of Corporatism?" in Review of Politics, vol. 36, pp. 85-131.

- 1981. "Interest Intermediation and Regime Governability in Contemporary Western Europe and North America", in Organizing Interests in Western Europe, edited by Suzanne D. Berger (Cambridge: Cambridge University Press), pp. 285-327

Siaroff, Alan. 1999. "Corporatism in 24 Industrial Democracies: Meaning and Measurement." In European Journal of Political Research, vol. 36, pp. 175-205.

Soskice, David. 1990. "Wage Determination: The Changing Role of Institutions in Advanced Industrialized Countries", in Oxford Review of Economic Policy, vol.6, No. 4, pp. 36-61.

Streeck, Wolfgang. 1992. Social Institutions and Economic Performance: Studies of Industrial Relations in Advanced Capitalist Economies.(London: Sage).

Swank, Duane. 2001. "Political Institutions and Welfare State Restructuring: The Impact of Institutions on Social Policy Change in Developed Democracies", in The New Politics of the Welfare State, edited by Paul Pierson (Oxford: Oxford University Press).

Swank, Duane and Cathie Jo Martin. 2001. "Employers and the Welfare State: The Political Economic Organization of Firms and Social Policy in Contemporary Capitalist Democracies", in Comparative Political Studies, vol. 34, pp. 889-923.

Tálos, Emmerich and Bernhard Kittel. 2001. Gesetzgebung in Österreich. Netzwerke, Akteure und Interaktionen in politischen Entscheidungsprozessen (Wien: Wiener Universitätsverlag). 
Traxler, Franz. 1995. "Farewell to Labour Market Associations? Organized versus Disorganized Decentralization as a Map for Industrial Relations" in Organized Industrial Relations in Europe: What Future? edited by Colin Crouch and Franz Traxler (Aldershot: Avebury).

Traxler, Franz, Sabine Blaschke, and Bernhard Kittel. 2001. National Labour Relations in Internationalized Markets (Oxford: Oxford University Press).

Traxler, Franz and Bernhard Kittel. 2000. "The Bargaining System and Performance: A Comparison of 18 OECD Countries" in Comparative Political Studies, vol. 33, pp. 1154-90.

Troy, L., C. T. Koeller, and N. Sheflin. 1980. "The Three Faces of Unionism" in Policy Review, Fall, pp. 95-109.

van Deth, Jan. 1998. "Equivalence in Comparative Political Research" in Comparative Politics: The oblem of Equivalence, edited by Jan van Deth (New York: Routledge).

Wallerstein, Michael. 1999. "Wage-Setting Institutions and Pay Inequality in Advanced Industrial Societies" in American Journal of Political Science, vol. 43, pp. 649-680.

Weede, Erich. 1996. Economic Development, Social Order, and World Politics (Boulder, CO: Lynne Rienner). 